Revista Iberoamericana, Vol. LXXVII, Núms. 236-237, Julio-Diciembre 2011, 885-917

\title{
ALTERNATIVAS TESTIMONIALES: GESTIÓN CULTURAL Y MEMORIA EN ARGENTINA
}

\author{
POR \\ GUILlERmina WaLAS \\ Investigadora independiente
}

If testimony is passion, that is because it will always suffer both having, undecidably [sic], a connection to fiction, perjury, or lie and never being able or obligated-without ceasing to testify-to become a proof.

Derrida, Demeure (27-28)

Las pasiones que el testimonio despierta y en las que se convierte, según lo definiera con tanta precisión Jacques Derrida, tienen que ver sin duda con esta oscilación sufrida entre el fluir de un relato que puede llenar los huecos de lo indecible o imposible de saber, cayendo en el límite de la mentira/perjurio/ficción o el congelarse en retazos de verdad, pruebas que una vez fijadas como escenas de museo pierden consistencia y fuerza o simplemente se archivan, cayendo de nuevo en el olvido, traicionando el fin que tuvo la enunciación o el registro de la memoria. Pero, tal vez el problema no es el testimonio en sí sino precisamente las materias primas sobre las que se funda: primero, la experiencia traumática de ver, presenciar, vivir algo a lo que muchos otros no sobrevivieron para contar, desde un lugar que no es el del victimario, o del poder, por lo cual todo testigo se asume como víctima en algún sentido, pero no del todo, ya que sobrevivió y por lo tanto, siempre queda bajo sospecha de traición; ${ }^{1}$ segundo, y más

\footnotetext{
1 Con este punto se relaciona, en una posible interpretación, el texto de Maurice Blanchot, "L'instant de ma mort" sobre el que se basa Derrida para su discurso en Demeure (2-11). Pero yendo al contexto que nos ocupa (el testimonio en Argentina), al respecto señala Pablo Daniel Bonaldi en su artículo sobre H.I.J.O.S. (Hijos por la Identidad y la Justicia contra el Olvido y el Silencio) que una de las grandes diferencias entre esta agrupación y las Madres de Plaza de Mayo, bajo el liderazgo de Hebe de Bonafini, es que este segundo grupo tiende a descalificar, como otros sectores de la sociedad argentina, la versión de los sobrevivientes "por sospechar que colaboraron con los represores", estableciendo "una distinción tajante y excluyente entre los que murieron y los que no" (162-63) y quitando así legitimidad al testimonio de estos últimos. Las hipótesis sobre el fracaso de los movimientos de la década de los setenta por la existencia de agentes dobles, infiltrados, o por la "quiebra" de pactos de silencio por parte
} 
polémico, está el recuerdo que es siempre subjetivo, único como la experiencia o incluso más, por sus recortes al registrarla y guardar ciertas partes en detrimento de otras; al convertirse en relato o salir a la luz en sus diferentes manifestaciones como "acto de presencia", ${ }^{2}$ esas subjetividades se agudizan según el estilo, voz que se adopte, contexto de enunciación, destinatario, forma y medio de expresión, entre otros factores. Así, el discurso de los sobrevivientes, basado en la actualización de una memoria traumática que con la dificultad de contar lo inenarrable se registra en formatos diversos (desde el documento expresamente jurídico hasta el relato fílmico, literario, pictórico, entre otros) que converge en un mar de cuestionamientos. ${ }^{3}$

En este trabajo, tras una ligera pero necesaria revisión de algunos puntos clave del debate sobre el discurso testimonial (que particularmente atañe a su forma narrativa, literaria y fílmica, pero no se limita a ello), con especial énfasis en el caso argentino y en los últimos años, propongo observar cómo algunas prácticas relacionadas con la memoria, cercanas al testimonio (no en su forma ortodoxa, pero igualmente definibles como manifestaciones afines). Estas prácticas ejercen como agentes en la construcción de una historia plural y que, aunque suelan ser centro de polémica, generan una discusión vital para el funcionamiento democrático de la sociedad a la vez que contribuyen a agilizar la acción jurídica, ${ }^{4}$ permitiendo la incorporación de partes que habían sido negadas al imaginario colectivo, por acción de la censura, intento de clausura, o por haber sido simplemente silenciadas (literalmente "desaparecidas") como muchos de sus protagonistas.

de secuestrados durante la tortura, aunque no están comprobadas, son parte del argumento de varios analistas, según lo observa Pilar Calveiro en Política y/o violencia (99-100, 128-32). Por su parte, Ana Longoni aborda específicamente dicho tema en Traiciones. La figura del traidor en los relatos acerca de los sobrevivientes de la represión (2007). También, remito a la entrevista realizada por Juan Terranova a esta autora, publicada en Perfil, en donde comenta la construcción de una dualidad por la cual el desaparecido es "héroe", pero el sobreviviente es "traidor". De tal manera, el relato, que sólo puede ofrecer este último, cualquiera sea su formato, es igualmente puesto bajo la lente de la sospecha. Convengamos que tal circunstancia contribuye al carácter trágico del testimonio de los sobrevivientes del campo de concentración y de la detención ilegal.

2 En este trabajo se utilizará el término "testimonio" en sentido amplio, como "acto de presencia", cuya “esencia no debe ser reducida necesariamente a una narración” (Derrida, Demeure 38, mi traducción), definición que comprende el concepto de testimonio como género literario pero va mucho más allá de ello, abarcando prácticas diversas relacionadas con el ejercicio de actualización de una memoria traumática tanto para el sujeto que rememora como para la colectividad que involucra.

3 En el caso argentino tales cuestionamientos se agudizan con el uso y abuso del término "testimonial" desde grupos de poder, como por ejemplo quedó explícito con el extraño concepto de "candidaturas testimoniales" que circuló durante las elecciones a diputados y senadores en junio de 2009.

4 Una prueba fehaciente de esto es, por ejemplo, la reciente disposición por parte de la Cámara de Casación de reasignar cuatro causas contra represores durante la dictadura para acelerar las sentencias o el fallo de la Corte (4 de abril, 2009). Los "escraches", "marchas" y "blogs" tuvieron mucho que ver con este adelanto.

ISSN 2154-4794 (Electrónico)
ISSN 0034-9631 (Impreso) 
Para hablar de dichas prácticas considero muy apropiado el concepto que en inglés se ha acuñado como cultural agency, es decir, el poder y capacidad de gestión esgrimido en el campo de la cultura. Este tipo de poder de gestión es entendido de acuerdo a lo que propone Doris Sommer como "una variedad de contribuciones sociales dadas a través de prácticas creativas"(1). ${ }^{5}$ Prácticas tales como los "escraches", que Pilar Calveiro, por ejemplo, considera "indispensables en la construcción de la memoria" (13) han sido abordadas por Diana Taylor, no sin causar polémicas, en sus artículos sobre los actos y actuaciones (performances) de organizaciones civiles aliadas entre sí, como el Grupo de Arte Callejero, Madres de Plaza de Mayo, Abuelas de Plaza de Mayo e H.I.J.O.S. (Hijos por la Identidad y la Justicia contra el Olvido y el Silencio), manifestándose de diversas formas en la lucha contra la impunidad y búsqueda de justicia, sobre todo desde fines de los años noventa. ${ }^{6}$ Otras prácticas de gestión cultural estarían dadas, por ejemplo, en la pintura de murales alusivos a hechos de la dictadura o conectados con el reclamo de memoria y justicia en conexión a esos y otros acontecimientos nacionales que atañen al "hoy" tanto como al "ayer". A pesar de no suponer la misma dinámica que un "escrache", 7 los murales son una forma de arte afín a los movimientos populares, al exponer e iluminar la historia, incluso profetizando el futuro (Bergman et al 214). Por su parte, los espacios conmemorativos donde se llevan a cabo actividades culturales de diversos tipos, así como los espacios virtuales que permiten al visitarlos "circular" por materiales de diferente procedencia y textura, muestran también aspectos de una gestión cultural activa a la vez que comparten con el discurso testimonial la recuperación

5 Ésta es mi traducción. En el original: "a range of social contributions through creative practices".

6 Remito a Taylor "DNA of Performance: Political Hauntology", publicado en Cultural Agency in the Americas, por Sommer, pero también a "You Are Here': H.I.J.O.S. and DNA of Performance" en The Archive and the Repertoire 161-87. Las observaciones de esta autora, si bien tendientes a apoyar la actividad de los grupos de Derechos Humanos involucrados (Madres, H.I.J.O.S., Grupo de Arte Callejero, entre otros), también causaron crítica y conmoción, sobre todo por la aplicación del concepto de teatralidad a prácticas destinadas a un reclamo muy concreto de justicia. Una lectura interesante acerca de lo controversial del análisis de Diana Taylor es la que efectúa Ana Forcinito en Memorias y nomadías, especialmente en la sección "Género, memoria y maternidad" (217-19).

7 Me refiero al hecho de que un mural en sí mismo no implica un "comportamiento reiterativo" por lo que entraría en la categoría del archivo (Taylor, "DNA" 52). Al no ser un acto que se repite con ciertas variaciones (como sucede con los "escraches"), "actúa" desde su estado fijo o rígido, como objeto escenográfico y su "actuación” tiene que ver con la recepción, es decir, con el impacto e interpretaciones que causa en quienes lo perciben, sobre todo en aquellos receptores/transeúntes que pueden observar el mural desde su producción (instalación) hasta su eventual borradura. Así el mural comparte más con los espacios conmemorativos que con otras actividades aparentemente más interactivas como los "escraches". Para una definición de "escrache" remito también a Taylor (Archive 164). Cabe aclarar que la mayoría de las prácticas que el presente proyecto aborda (y de las que este trabajo sólo ofrece una muestra) entran en la categoría del archivo según Taylor, pero que, sin embargo, cuando me refiero a la idea de "archivar" en términos generales estoy hablando simbólicamente de lo que se guarda y muchas veces se olvida, desvirtuando el propósito de su creación.

\begin{tabular}{l} 
Revista Iberoamericana, Vol. LXXVII, Núms. 236-237, Julio-Diciembre 2011, $885-917$ \\
\hline ISSN 0034-9631 (Impreso)
\end{tabular} 
de una memoria que surge de voces no antes escuchadas (por marginación, censura, silenciamiento) y un sentido de urgencia en el reclamo de justicia. ${ }^{8}$

La urgencia política, el reclamo de justicia, el "no" al olvido y al silencio, así como el trazado de vínculos solidarios son puntos que hacen del testimonio (en un sentido amplio de discurso de la memoria que requiere atención y da cuenta, atestigua, sobre un hecho o experiencia, singular y universalizable a la vez), particularmente necesario para formar una sociedad democrática y participativa que ha superado en la medida de lo posible sus peores traumas. ${ }^{9}$ Pero para ello, ese testimonio no puede quedarse en el ámbito jurídico, ni en el académico. Correspondería que las prácticas de la memoria, sobre todo si refieren y denuncian aspectos o acontecimientos que atañen a una sociedad, a un colectivo, aún cuando estén firmadas y sesgadas por una subjetividad particular, trasciendan la letra y el archivo. Y si en este sentido comprendemos la función didáctica que conllevan, esos discursos antes acallados, tampoco deberían quedar restringidos al ámbito escolar, tras ser mediados (quizás por enésima vez) y convertirse en capítulo de libro de texto, sino que necesitan ser considerados en las formas múltiples en que se presentan y representan en lo cotidiano, para que se haga evidente incluso para aquéllos que sigan sin querer "leer", "escuchar", "mirar" esa parte de la historia. Tal función, la didáctica, se logra en la incorporación analítica de diversas manifestaciones, sobre todo aquéllas que, en combinación con políticas del Estado o por iniciativa de grupos

8 Aunque no pretendo aquí entrar en la teorización del testimonio como género literario, cabe aclarar que al hablar en sentido amplio del discurso testimonial, en cualquiera de sus formas, adscribo a uno de los "requisitos" del testimonio narrativo, literario, que estas prácticas compartirían, según la bien difundida definición de John Beverley: "The situation of narration in testimonio has to involve an urgency to communicate, a problem of repression, poverty, subalternity, imprisonment, struggle for survival, implicated in the act of narration itself" "The Margin at the Center" en la versión publicada en The Real Thing, 26; en español, en Subalternidad y representación 103).

9 Es pertinente destacar aquí lo señalado por Alicia Partnoy en una de sus auto-reflexiones sobre la escritura testimonial: "testimonio is not about truth. Rather, the form serves as a tool for building a discourse of solidarity with victims of state terrorism."("On Being Shorter" 175, énfasis en el original). Cabe agregar que éste es uno de los artículos críticos más agudos en torno del discurso testimonial a los que he tenido acceso. El planteo desde lo personal muestra una intensa lucidez muchas veces ausente en otros ensayos que se dicen "objetivos". Hay que destacar además que la solidaridad de la que habla Partnoy no viene de un "hablar por otros" (ella habla por sí misma) por lo cual no es la solidaridad demagógica que marcó el fracaso de los estudios subalternos en (¿o sobre?) América Latina según la autocrítica de Beverley en Subalternidad y representación (70-71). Agrego que el tema de la solidaridad también está presente, aunque tímidamente, en uno de mis trabajos (ya anacrónicos) sobre el testimonio de Rigoberta Menchú al hablar de las alianzas que se establecen para la creación del texto como objeto material tanto como su función como arma política de denuncia (Walas, "Autobiografía-etnografía" 662). Mi propuesta consistía en pensar esa alianza como una ruptura temporaria de barreras de clase, etnia, etc., en pro de un fin común, lo que es bastante diferente (tal vez por ingenuo) del sentido de solidaridad según lo articulan algunos académicos consagrados. Respecto de lo "singular y universalizable" de la experiencia testimonial remito nuevamente a Derrida (Demeure 41).

Revista Iberoamericana, Vol. LXXVII, Núms. 236-237, Julio-Diciembre 2011, $885-917$
ISSN 2154-4794 (Electrónico) 
independientes suscriben a una re-escritura permanente, inclusiva de nuevas voces y perspectivas, que vienen de y llegan al imaginario social.

En su introducción a Cultural Agency in the Americas, Doris Sommer también destaca una urgencia: la de enfocar en el estudio de prácticas creativas, intelectuales y de activismo que ejercen cierto poder de gestión en la cultura, ya sea que ese influjo cultural se produzca directa o indirectamente (8), puesto que estas prácticas se constituyen como un tipo de voz política que renueva nuestras esperanzas respecto del mundo (20). ${ }^{10}$ De tal manera, propongo observar algunas prácticas relacionadas con los reclamos de la memoria, deteniéndome específicamente en los espacios destinados a tal fin, para luego preguntarnos sobre la función testimonial de los mismos, en tanto fuentes de historización, y su lugar en la promoción de una sociedad democrática en la que la historia es percibida, al menos en un plano simbólico, como propiedad de todos, al ser escuchada en sus diferentes campañas y al trazarse mediante ella nuevos lazos de solidaridad.

Pasiones del discurso testimonial DESDE y SOBRE Diferentes “ESCUElas"

Beware: in little schools the boundaries between story and history are so subtle that even I can hardly find them. Partnoy, Introducción a The Little School (18)

En Latinoamérica como en otras regiones que han pasado por acontecimientos traumáticos, históricamente oscuros y divisivos de la opinión pública, el discurso testimonial, en sus múltiples manifestaciones posibles, se hace instrumental y clave, sobre todo a partir de los procesos de pacificación y transición democrática, y en lo que respecta a la arena jurídica, a los reclamos de esclarecimiento y justicia por parte del cuerpo social. Por ejemplo, el informe de la CONADEP (Comisión Nacional sobre la Desaparición de Personas), más conocido como Nunca Más (1984) en el caso argentino inicia o es la llave mayor que abre las puertas del lento juicio a las juntas militares, que tras altibajos tales como las leyes de Obediencia Debida (junio de 1987) y de Punto Final (diciembre de 1986) o los indultos menemistas (1989 y 1990), podría decirse que todavía continúa, siguen surgiendo testimonios y lamentablemente, "faltando" testigos como el desaparecido Jorge Julio López, de quien no se conoce paradero desde septiembre de 2006. ${ }^{11}$ Sin testigos, sin testimonio, es dificultoso, si no imposible, el proceder de la

${ }^{10}$ He parafraseado la segunda referencia a Doris Sommer con mi interpretación. Textualmente, en inglés: "Cultural agency is a name for the kind of political voice that speaks through aesthetic effects and that can renew love for the world" (19-20).

11 Aunque el gobierno ha ofrecido y sigue ofreciendo recompensa por información sobre López, se puede ver en las pintadas, marchas y en una parte de la opinión pública la acusación de complicidad por parte

ISSN 0034-9631 (Impreso) 
justicia y sin justicia se pone en jaque, a su vez, la consolidación democrática. Por eso, ante políticas débiles y cambiantes por parte del Estado, la acción de grupos civiles adquiere vital importancia para evitar la impunidad y el olvido.

En la esfera primariamente literaria, el lugar trascendente y polémico del discurso testimonial es incluso anterior a esta etapa de transición y se conecta más con el período revolucionario o diríamos posrevolucionario, en tanto se da tras el triunfo de la revolución cubana: desde la instauración del Premio Casa de las Américas, que lo convierte de alguna manera en género literario (1970), principalmente en lo que respecta a Centroamérica, el testimonio llega a ser un discurso que ofrece mucha tela que cortar, sobre todo en los años noventas, en parte por intervención de la academia norteamericana que al verlo como transgresor y revolucionario termina por quitarle esta misma característica que aplaudiera. ${ }^{12}$ Así, a la vez que se piensa el fracaso revolucionario en lo que atañe a Centroamérica, en especial, en los noventa se cuestiona el rol y posibilidad transgresora del testimonio en su relación con la literatura y la política. Pero, yendo al terreno específico del Cono Sur, el testimonio sobresale como objeto de análisis, teorización y debate, como dije antes, a partir y respecto de la transición, como una apertura a contar, discutir y analizar los relatos posibles en el marco que de a poco comienza a posibilitar la democracia, y sobre todo, como otra estrategia para impulsar los juicios a las juntas militares. No se suscitó en este contexto un interés desde la especificidad de la crítica literaria por el testimonio en su calidad de discurso subjetivo de la memoria, ${ }^{13}$ como

del gobierno o de "no hacer lo suficiente" para encontrarlo o para prevenir que su desaparición (por segunda vez) se materializara. Ver imágenes adjuntas al final del trabajo, por ejemplo.

12 Me hago eco aquí de lo que ya señalara Georg Gugelberger en su introducción a The Real Thing para explicar este fenómeno, siguiendo conceptos deleuzianos: "Deterritorialization is bound to be reterritorialized; every anti-discourse is bound to be co-opted; there always is restitution even in subversion" (17-18). Cabe aclarar sin embargo que no sigo en mi trabajo la distinción de Gugelberger y otros en dicha colección de artículos entre "testimonio" en Latinoamérica y "testimonial discourse" en el resto del mundo (4), en tanto considero que esa división responde a una posición que busca enaltecer la capacidad subversiva del testimonio, pero que en definitiva también termina por desacreditar a la voz testimonial (por cuestionar si habla o no desde su "subalternidad" y hasta qué punto esta condición se mantiene o pierde en su trascendencia). Por supuesto, esto sería tema para otro trabajo: valga aquí sólo como aclaración sobre mi postura al respecto.

13 Se debe aclarar que desde mediados de los años ochenta surgen numerosas publicaciones sobre la narrativa de "no-ficción" en Argentina, pero en ellas la palabra "testimonio" refiere en la mayoría de los casos a materiales utilizados para construir la narrativa y no a la narrativa en sí. También en esta etapa la discusión se emparenta con los planteos revolucionarios de Hayden White, entre otros, sobre la narrativa histórica, sin entrar de lleno en las implicancias éticas y políticas que postulan los testimonios de sobrevivientes, quizás por considerarse éstas como ajenas al campo de estudio o, en cambio, por ser el tema una "herida a flor de piel", difícil de tratar con cierta distancia. Sin embargo, cabe aquí destacar de las teorizaciones sobre la llamada "literatura factual" dadas en ese contexto (mediados de los ochenta y principios de los noventa), lo señalado por Ana María Amar Sánchez al decir que "el género ["novela de no-ficción" o "testimonial"] se juega en el cruce de dos imposibilidades: la de mostrarse como una ficción, puesto que los hechos ocurrieron y el lector lo sabe y, por otra parte, la imposibilidad de mostrarse

Revista Iberoamericana, Vol. LXXVII, Núms. 236-237, Julio-Diciembre 2011, 885-917 ISSN 0034-9631 (Impreso) 
en todo caso y más recientemente en la esfera interdisciplinaria de la crítica cultural, donde todavía nos ocupa en debates que suponen "pasión" en varios sino en todos los sentidos de dicho término, según Derrida expone en su ya citado Demeure (26-28).

Precisamente, esta "pasión" o, para usar las propias palabras de la autora que nos compete en esta sección, esta "fuente inagotable de vitalidad polémica" que es "la impureza del testimonio" (Sarlo, Tiempo pasado 80), a nivel de la discusión académicointelectual y respecto del testimonio no estrictamente jurídico, se hizo más visible en el Cono Sur en 2005, entre otras eventualidades, con la aparición de Tiempo pasado, aparente continuación de la serie de crítica cultural que Beatriz Sarlo comenzó con los artículos periodísticos de Tiempo presente (2001). En estos artículos ya se anticipaba que se había abierto "el capítulo de la memoria" y que "los crímenes de la dictadura militar son la materia de una reflexión filosófica, historiográfica, moral y estética" (Tiempo presente 43), pero sin convertir al tema en centro de atención o análisis. Hasta allí, todos de acuerdo.

El argumento de Tiempo pasado. Cultura de la memoria y giro subjetivo, en cambio, le hizo honor a su último subtítulo (Una discusión), despertando más de una discusión -aunque con quién o quiénes se discute es algo abierto a la interpretación del lector o tal vez vale pensar que se trata de una auto-discusión-y por ello me interesa detenerme en algunos de sus planteos. ${ }^{14}$ En primer lugar, a pesar de su fortaleza en lecturas teóricas sobre la memoria, el texto despliega contradicciones en su análisis de aquellos discursos en primera persona producidos en relación al tema del terrorismo de Estado por voces que fueron de diferentes maneras víctimas del mismo, pero además porque en proporción con la teoría (principalmente europea y relacionada con el Holocausto, desconectada en apariencia de las discusiones sobre el testimonio en Latinoamérica), son pocos los testimonios del área en cuestión que analiza para demostrar su hipótesis: el planteo inicial hace pensar que habría una superabundancia de producciones testimoniales en Argentina (que quizás la hay de hecho y de manera muy legítima, pero no es lo que queda ejemplificado en el libro); en contraste, como lector se llega a la conclusión de

como un espejo fiel de esos hechos" (Relato 19). Poniendo a dialogar esta cita con la de Jacques Derrida que utilizamos para comenzar, es interesante notar que, para Amar Sánchez, es en el relato literario donde precisamente se logra resolver la tensión entre "ficción" y "realidad". El problema es cuando entendemos el relato trascendiendo o afuera de los límites del campo literario.

14 Tiempo pasado merece especial atención aquí, entre otras cosas, por su conexión con los debates en torno a la memoria que se estaban dando en la sociedad argentina, aunque el texto explícitamente no lo mencione: el paso de la ESMA a manos civiles, del que se hablará más adelante. Como Sarlo comenta en una entrevista del diario Clarín, el libro "está recortado contra ese problema, en el libro ese problema no está tocado, pero yo sí podría decir que la cuestión de cómo debe pasar un museo en la memoria de los años '70 me parece fundamental y es como el telón de fondo de este libro" ("Tiempo pasado", énfasis en el original). La conclusión de la autora en dicha entrevista es que el testimonio en primera persona presenta "una verdad que sólo funciona a nivel jurídico": otra paradoja, quizá.

\footnotetext{
$\begin{array}{lllll}\text { Revista Iberoamericana, Vol. LXXVII, Núms. 236-237, Julio-Diciembre 2011, } & 885-917 \\ \text { ISSN 0034-9631 (Impreso) } & \text { ISSN 2154-4794 (Electrónico) }\end{array}$ 
que no sería así a juzgar por el reducido corpus que se analiza que, por otra parte, se hace presente recién pasada la página setenta del libro y a cuenta gotas.

Uno de los primeros textos no teóricos y pertinente al planteo que Beatriz Sarlo aborda es justamente el de Alicia Partnoy que citamos para iniciar esta sección, La escuelita o The Little School, del que la crítica argentina parece haber tenido noticia reciente aunque el texto fue publicado en el exilio, en inglés, en $1986 .{ }^{15}$ Por esta razón el texto no pertenece a ninguna nueva ola o moda memorialista surgida en el cambio de siglo, sino que corresponde a la ya mencionada "apertura" que se hizo posible en la transición democrática, apenas restablecido el Estado de Derecho. En general, el análisis de Sarlo se basa en la ya clásica oposición entre discurso subjetivo (léase testimonio) versus objetividad analítica, cientificista, a la que aspira el discurso histórico concebido en términos tradicionales (objetividad que ya sabemos inalcanzable). Sin embargo, lo que se lee entre líneas es otro discurso, uno que limita la narrativa testimonial a un pasado sobre el que no se puede actuar más que mediante la interpretación en/de terceras personas. Sarlo rescata aquellos textos donde la primera persona aparece más mediada (por ejemplo cuando se recogen testimonios desde una tercera persona que organiza y selecciona), pero acusa de poco reflexivos a esos otros en que el testigo/ sujeto testimonial es quien habla y firma.

Así, la propuesta de Tiempo pasado resulta paradójica, lo que es tal vez un rasgo inteligentemente premeditado para provocar la discusión, y por eso, aún más digno de destacar. Es paradójica primero, porque en la crítica al subjetivismo testimonial se hace evidente otro subjetivismo: el de la crítica misma. Luego, es aún más paradójica cuando leemos esa crítica teniendo en mente lo que justamente Alicia Partnoy señalara en la introducción a su testimonio, donde explica los motivos que la llevaron a la participación política: que el objetivo principal que tenía ella y sus compañeros (usa la primera persona plural) era cambiar el concepto de las universidades como islas de intelectuales que no se comprometían con la realidad del país (The Little School 12). ${ }^{16}$ Aunque no caben dudas del compromiso de Sarlo con la realidad del país, su propuesta parecería indicar que sólo son los intelectuales/académicos quienes tienen el derecho interpretativo y de intervención, y luego que la literatura (consagrada) es el mejor lugar para relatar y, por ende, representar el pasado (Tiempo pasado 163). Esto está ligado al tratamiento del tema de la verdad, sólidamente razonado desde lo teórico, pero del que

\footnotetext{
${ }_{15}$ Muchos ex-detenidos/desaparecidos comenzaron a dar testimonio desde el exilio; de allí que el texto de Alicia Partnoy haya salido a la luz en su edición en inglés. El título refiere al nombre dado por los captores al centro de detención ilegal en el que estuvo secuestrada la autora en Bahía Blanca. En la actualidad, el testimonio de Partnoy, además de hacerlo en su formato literario, circula en la red: <http://www. desaparecidos.org/arg/conadep/bahia/escuelita.html $>$.

${ }^{16}$ Cito: "At my home town university in Bahía Blanca, I began to get involved. Our main goal was to change the concept of universities as 'islands' for scholars who were not concerned with the country's reality."

ISSN 2154-4794 (Electrónico)
ISSN 0034-9631 (Impreso)
} 
se desprende una lectura visceral: la de creer que el testimonio o los discursos en primera persona sobre la experiencia traumática, quizás en su deseo de justicia, pretenden ser la única y pura verdad.

Es en su contradicción respecto de la necesidad de recuperación de la(s) memoria(s) con sus diferentes versiones, verdades, etc., que el argumento de Tiempo pasado resulta preocupante, puesto que la memoria no es algo que simplemente conecta al pasado y se reduce a él. Como la misma autora lo reconoce (aunque parece olvidarse de ello en el centro de su argumentación), la memoria es un fenómeno conectado con el presente; es, de hecho, lo que nos permite relacionar pasado y presente. ${ }^{17}$ Por lo cual, pensar la memoria como algo que es "tiempo pasado" nos trae la frase popular y nefasta "lo pasado, pisado". Aunque respecto de tal actitud Sarlo se defiende de antemano aclarando que está en el grupo de los que consideran que el "nunca más" no debe ser un cierre a la discusión, también aclara que esto debe estar acotado al campo jurídico (24-25), lo cual resulta un tanto reductivo y priva a la opinión pública -sobre todo a aquéllos a quienes la historia no los tocó tan de cerca, ya sea por una cuestión generacional u otra no relacionada estrictamente con la posición política- de escuchar una pluralidad de discursos surgidos de memorias, ideologías y puntos de vista diferentes, incluso enmarcadas en registros de semi-ficción, y que permiten el compromiso democrático representado por una opinión o postura frente a los hechos antes desconocidos; tales versiones testimoniales en primera persona no creo que pretendan dar una verdad total y absoluta, sino ofrecer partes antes silenciadas de la historia para que cada uno haga sus propias interpretaciones, lecturas y conjeturas. Precisamente, estos relatos de la experiencia traen el pasado al presente para su revisión interpretativa de la pluralidad que conforman las distintas subjetividades dentro de ese cuerpo colectivo que es la nación. Además, si el problema fuera la retórica dada por la primera persona, la misma no debería ser motivo de descrédito por sí misma porque es precisamente la primera persona, la intimidad de la experiencia y de ese enfrentamiento con la muerte del que habla Maurice Blanchot, lo que en parte concede su condición particular al discurso

17 Destaco aquí la frase de Pierre Nora con la que Diana Taylor comienza su ensayo "DNA of Performance: Political Hauntology" (52). Sarlo señala, haciendo referencia a Bergson y a Deleuze, que el pasado se hace presente, que el tiempo propio del recuerdo es el presente (10), y luego al final se reconoce que es en el presente que el pasado se decodifica (159), en cambio, en su desarrollo ese mismo argumento parece basado en la interpretación aristotélica de que "toda memoria es del pasado" (Ricoeur 8). Sin embargo, en el pasado, perteneciente por completo al pasado y que el intentar "revivirla" trae el problema de convocar a la infiel imaginación (no sólo en el sentido actual sino en el de imágenes distorsionadas), lo cual es un recurso precioso y nada infiel para Sarlo si y sólo si el relato se enmarca en lo propiamente literario con un narrador que "maneja" a sus personajes. Recordemos aquí que la memoria en una conexión unidireccional con el pasado también comporta lo trágico de lo irrecuperable e irreparable. Sin embargo, según concluye Paul Ricoeur al respecto, el ejercicio de la memoria, interpretable como traer las imágenes del pasado al presente, es una función cognitiva y fiel en tanto busca una verdad (55).

Revista Iberoamericana, Vol. LXXVII, Núms. 236-237, Julio-Diciembre 2011, 885-917
ISSN 0034-9631 (Impreso) 
testimonial. En todo caso, qué pasaría si nos enfrentáramos a una narración en primera persona, pero de autor/productor anónimo (un sujeto que no mostrara su rostro a la cámara ni firmara lo dicho con nombre y apellido): ¿eliminaría esto, acaso, el prurito que provoca en la crítica el uso de la primera persona? La crítica al testimonio en Tiempo pasado es, en suma, una continuación de otras críticas de la autora hacia cuestiones o tendencias de "la vida posmoderna". ${ }^{18}$

Entonces, el argumento en base a una inteligente cita de Susan Sontag -"es más importante entender que recordar, aunque para entender sea preciso, también, recordar" (citado en Sarlo, Tiempo pasado 26)- pretende ser en sí mismo el discurso autorizado o de autoridad, que pone a la academia y al juicio intelectual por encima de cualquier otro punto de vista (curiosamente algo contrario a lo que aboga su conocida revista, defensora de la pluralidad de "puntos de vista"). ${ }^{19}$ Esto último es lo más discutible de la "discusión", ya que se lee como la negación de toda posibilidad de gestión discursiva para aquéllos que quieren contar su vivencia desde su lugar que puede no ser el de la autoridad intelectual, económica o política, ni querer recurrir a la ficción de desdoblarse o camuflarse en un personaje literario o bajo un narrador en tercera persona. ${ }^{20} \mathrm{Si}$ a esto

${ }^{18}$ Me refiero a los planteos que ya aparecían en 1994 en su Escenas de la vida posmoderna. La crítica dada allí en el último capítulo ("Intelectuales", Escenas 113-98), continúa de alguna manera en Tiempo pasado en tanto hay silencios que hablan por sí mismos en el texto, como por ejemplo la ausencia de toda referencia al debate latinoamericano en torno al testimonio y la escasísima (o "muy selecta" para verlo de otro modo) presencia de críticos norteamericanos, menos aún latinoamericanistas, que han tomado partido sobre testimonio y posmodernidad.

${ }^{19}$ Indudablemente estamos de acuerdo con lo citado de Susan Sontag y aplaudimos esta parte de la iniciativa de Sarlo que dio visibilidad a la importancia de lo interpretativo según lo demuestra por ejemplo un artículo del diario Clarín sobre la ESMA (<http://www.clarin.com/suplementos/zona/2008/03/23/z-03115.htm>), entre otras publicaciones. Por supuesto que ningún texto, discurso o producción debe ser "intocable" para el análisis crítico. Sin embargo, Sarlo despliega a partir de su uso de esta cita una polémica que como puede verse daría para otro trabajo específico al presentar al discurso crítico como el único autorizado para discutir cualquier cosa; cabe aclarar aquí, por si hiciera falta, que respetuosamente disiento en varios aspectos con lo que considero una postura elitista y enajenante de ciertas producciones relacionadas con el testimonio y la memoria en Argentina. Para una respuesta sagaz de alguien a quien el texto de Sarlo le incumbe más directamente, remito a Alicia Partnoy, "Cuando vienen matando" (PMLA 121/5). Otras respuestas positivas y negativas circularon en los medios de prensa y en la red (por ejemplo, $<\mathrm{http}: / /$ www.loescrito.net/index.php?id=132>; $\quad<$ http://www.amphibia.com.ar/el-giro-subjetivo-segun-sarloy-la-tentadora-inflacion-teorica-de-lash/>; $\quad<$ http://desdeelaula.blogspot.com/2005/10/beatriz-sarlo-ysu-tiempo-pasado.html>; o algunos más académicos como "Aduanas de la memoria" en $<\mathrm{http}: / / \mathrm{www}$. rayandolosconfines.com.ar/critica kaufman.html >), y es muy posible, aunque no poseo constancia que dé fe de ello, que también se haya debatido acaloradamente en las aulas de la UBA (Universidad de Buenos Aires).

${ }^{20}$ Esto está demostrado en el hecho mismo de que la autora sí se permite la primera persona en varias partes del texto, dada su autoridad como intelectual. Son sobre todo curiosas las últimas páginas que dan "testimonio" de su postura actual: "Si tuviera que hablar por mí..." a lo que le sigue la selección de tres novelas de autores consagrados (magníficos escritores, pero además, "amigos" de la autora) (Escenas

Revista Iberoamericana, Vol. LXXVII, Núms. 236-237, Julio-Diciembre 2011, 885-917 ISSN 0034-9631 (Impreso) 
le agregáramos la cita que en señal de alerta hace Doris Sommer de un comentario de Rigoberta Menchú (en el congreso de la Asociación de Estudios Latinoamericanos, LASA, de 2002), acerca de la crítica como "signo de privilegio" (4) -comentario, sin duda, perspicaz- la perspectiva acerca de un conocimiento democrático y lo que es más, democratizador, sobre el pasado, resulta bastante desmoralizante. Sin duda, la crítica es una práctica fútil, sin salida, si no promueve un cambio. ${ }^{21}$

Continuando, más importante quizás que lo que proponen las posibles lecturas de un libro o incluso de un conjunto de ellos que acotan su mirada a la escritura, si queremos pasar de las palabras a la acción, el debate en torno a la memoria-y por ende, al testimonio como forma principal de representación de la misma- tuvo como eje pasional ciertos hechos dados alrededor del cumplimiento de los treinta años del golpe militar en marzo de 2006, y antes, incluso, en la reapertura de los juicios que habían sido detenidos por las "Leyes del Perdón", las cuales fueron declaradas inconstitucionales por parte de la Corte Suprema de Justicia en Argentina tras un largo proceso que fue del 2001 al 2005 (las leyes de Punto Final y Obediencia Debida se anularon en junio de 2005). Esto dio la posibilidad de considerar más documentación para los juicios reabiertos, pero como ya se mencionó, también llevó a un nuevo sentimiento de inseguridad para los testigos sobrevivientes de esa época nefasta, sobre todo a partir de la desaparición de Jorge Julio López en la ciudad de La Plata. Luego, hay que mencionar el auge de las discusiones en el ámbito de la opinión pública (tanto como a nivel gubernamental) respecto de los hoy llamados "espacios de la memoria" y de qué hacer con ellos: lugares que sirvieron para la detención ilegal y la tortura y que, a pesar de representar literalmente una "mala memoria" (en el sentido de una memoria terrible, traumática) para la historia de los países de la región, no deben ser sujetos a otro tipo de concreta mala memoria, la de una que no registra lo acontecido o que encubre ciertos hechos. Por el contrario, deben ser especialmente recordados y dicho recuerdo analizado, documentado, re-presentado.

205). Parece deducirse que, después de todo, para la crítica, nada es mejor que el poder de gestión que ejerce la literatura (en el sentido canónico), puesto que si bien "no disuelve todos los problemas planteados, ni puede explicarlos [...] en ella un narrador siempre piensa desde afuera de la experiencia, como si los humanos pudieran apoderarse de la pesadilla y no sólo padecerla" (Tiempo pasado 166, énfasis en el original). Pero ¿es que sólo en la ficción podemos "apoderarnos de la pesadilla"? ¿No deberíamos intentarlo concretamente en el día a día y en el terreno extra-literario como ciudadanos para exorcizar el pasado y que no se repita? Por último, me pregunto ¿dónde quedó la Beatriz Sarlo que exaltaba el texto testimonial, en primera persona en su mayor parte, de Antonio Marimón, El antiguo alimento de los héroes (1988) por ser al mismo tiempo "poema" y "testimonio", narración del recuerdo, y crítica de lo narrado, y que afirmaba vehemente "que la memoria y la escritura de la memoria son la única garantía para que el pasado exista con un sentido humano?" (Sarlo, "Sobre El antiguo alimento" 230).

${ }^{21}$ Cito: "But critique can dead-end if it doesn't nudge toward change. As an end product, Rigoberta Menchú quipped informally at the Latin American Studies meeting in 2002, critique is a sign of privilege. Poor people need a next step" (Sommer 4).

$\begin{array}{lllll}\text { ISSN 2154-4794 (Electrónico) } & \text { Revista Iberoamericana, Vol. LX1 (Impreso) }\end{array}$ 
Específicamente, la discusión sobre el discurso testimonial y sobre el testimonio que ofrecen tales "espacios de la memoria" se relaciona con el surgido sobre el predio de la ex ESMA (Escuela de Mecánica de la Armada) que recomenzara a partir del anuncio del entonces presidente Néstor Kirchner el 9 de febrero de 2004 de convertir el lugar en un museo o espacio testimonial de las atrocidades allí acontecidas. ${ }^{22} \mathrm{~A}$ partir de este "gesto" del gobierno que tuvo una acogida positiva en general, no sólo por parte de los grupos de Derechos Humanos y sectores políticos afines con el ejecutivo, comenzó un cuestionamiento relacionado con la puesta en práctica o las acciones a seguir. ${ }^{23}$ La sociedad se preguntaba si se trataba solamente de un acto simbólico o si habría realmente una expropiación del predio; quién o quiénes dispondrían del predio tras la expropiación, es decir, si concretamente pasaría a manos de la sociedad civil en su conjunto, a través de las Organizaciones de Derechos Humanos y otros grupos no gubernamentales. Otro cuestionamiento, atenuado pero aún vigente, refiere a los usos concretos de los edificios del predio. Un eje particular de la polémica giraba en torno a si debería mantenerse el funcionamiento de la Escuela en el mismo predio, es decir, hacer la expropiación en cierta medida parcial. Al respecto, el gobierno, siguiendo la opinión de las entidades y grupos comprometidos con el proyecto acerca de la imposibilidad de convivir nuevamente con los militares en ese espacio, anunció que el traslado de la Escuela a otro edificio, ajeno al predio y en el barrio de Retiro, se haría efectivo en 2006 y de hecho así ha ocurrido (aunque con cierto retraso, ya que se terminó de concretar el traspaso en septiembre de 2007), a pesar de las quejas y descontento de los padres y docentes de la institución. ${ }^{24}$ El campo de deportes es la única zona aún no incluida en

${ }_{22}$ El predio ya había sido materia de discusión durante la presidencia de Carlos Menem, en 1998, cuando se decretó también la mudanza de la ESMA para destinar el sitio a un espacio de memoria. La polémica surgió porque el plan del gobierno de entonces era demoler los edificios y convertir el lugar en un parque "símbolo de la unión nacional". Esto, además de la política de supuesta "reconciliación", tenía que ver con algo propio del gobierno neoliberal menemista: el plan de construcción de varias torres de departamentos cuyo valor inmobiliario incrementaría con una zona verde aledaña al río. La movilización social logró que el plan no se cumpliera y en ese mismo año se declarara a la ESMA como "patrimonio cultural de la Nación". Si bien no se efectuó el traslado de los militares del predio, por lo menos se impidió así un definitivo "borrón" que hubiera afectado en mucho la comprobación de datos para la justicia, y sobre todo, la memoria colectiva.

${ }^{23}$ En el diario Página/12, ya dados los primeros pasos, aunque aún percibidos como simbólicos, en la conversión del predio en "museo" o Espacio para la Memoria (visita y actos del 24 de marzo de 2004), aparece una encuesta que determina que seis de cada diez entrevistados están de acuerdo con la iniciativa y un $70 \%$ de la población (a juzgar por la encuesta) considera que la medida ayuda a terminar con la impunidad de lo sucedido en los años setenta. También en la misma proporción los encuestados consideran que la postura del gobierno respecto de la memoria contribuye a una sociedad más democrática y a educar a las nuevas generaciones (Kollmann, "Seis de cada diez").

24 Ver Vezzetti. También en Pagina/12 del 20 de marzo de 2004, por ejemplo, aparece una nota al respecto en la página 3. Además, a propósito de este tema del traslado puede verse como ejemplo de la reacción opositora la opinión de un diputado por la ciudad de Buenos Aires: Martín Borrelli en su artículo "ESMA:

Revista Iberoamericana, Vol. LXXVII, Núms. 236-237, Julio-Diciembre 2011, 885-917 ISSN 0034-9631 (Impreso) 
el Espacio para la Memoria -Ex ESMA, que sigue siendo disputada y especialmente reclamada por los familiares de desaparecidos en tanto piensan, justificadamente, que allí podrían encontrarse los restos de sus seres queridos- ${ }^{25}$

Además, este debate se ha materializado tanto en los medios, incluida la Internet, como en textos de factura interdisciplinaria como Memoria en construcción (2005) de Marcelo Brodsky. Este trabajo, cuyo subtítulo precisamente es "el debate sobre la ESMA" y donde por supuesto se apoya la iniciativa del Espacio para la Memoria, es propiamente testimonial en su abordaje de la memoria a través de fotografías, ${ }^{26}$ planos del predio, el trazado de su historia “oficial" (la historia dada desde un orden hegemónico sobre el espacio territorial, incluyendo su designación como Escuela de Mecánica de la Armada), testimonios concretos de detenidos allí que definen la historia "no oficial" del predio (como campo de concentración y maternidad clandestina), y finalmente la propuesta de hacer de éste un espacio abierto al público. Aunque, como se señala, la autoría es asumida por Marcelo Brodsky, se trata de un texto colectivo que no sólo remite al pasado sino que anticipa la puesta en práctica del proyecto Espacio para la Memoria, el cual, a pesar de estar todavía "en construcción”, va dejando de ser mero proyecto y concretándose (por supuesto con las infaltables idas y venidas): el predio está abierto al público interesado, ofrece visitas guiadas al Casino de Oficiales, el recorrido de las zonas externas (a excepción del ya mencionado Campo de Deportes, todavía en manos de la Armada), y además funciona allí el Archivo Nacional de la Memoria, la Secretaría de Derechos Humanos y el Centro Cultural de la Memoria "Haroldo Conti" en la ex Escuela de Guerra Naval (dependientes del Gobierno Nacional), y el ECuNHi (Espacio Cultural Nuestros Hijos), ubicado en el edificio que fuera del Liceo Naval y en manos de las Madres de Plaza de Mayo.

Regresando a la discusión sobre el museo y la expropiación, tal vez es el planteo de Hugo Vezzetti, en un ensayo de opinión publicado a tres meses del acto del 24 de marzo del 2005, el que mejor articula los miedos, algunos bien fundados, de la intelectualidad (esos que Sarlo disfraza en la preocupación por el subjetivismo de lo testimonial, al "recortar" del discurso la cuestión de la ESMA): 1) la intervención del Estado de manera arbitraria, que suena a autoritaria, en lugar de una acción por consenso ${ }^{27}$-Vezzetti destaca

memoria sin reconciliación" acusa al gobierno (nacional y de la ciudad de Buenos Aires) de falta de patriotismo y desperdicio del "valioso" espacio físico (haciendo hincapié literalmente en lo económico).

25 Remito aquí nuevamente a Página/12, "La historia sin fin de la ESMA" por Adriana Meyer.

${ }^{26}$ La mayoría de las fotografías de la etapa en que la ESMA funcionó como campo de concentración se las debemos a Víctor Basterra, un sobreviviente ex detenido en el predio que hoy ejerce como miembro del Consejo Directivo del IEM (Instituto Espacio para la Memoria).

${ }^{27}$ Esta visión por parte del público se debe a que la medida sobre la expropiación y el museo trascendió en los medios como una decisión del presidente de turno (Néstor Kirchner), pero en realidad, según lo que aparece documentado en la folletería del Instituto Espacio para la Memoria tanto como en su sitio virtual,

\footnotetext{
\begin{tabular}{l} 
Revista Iberoamericana, Vol. LXXVII, Núms. 236-237, Julio-Diciembre 2011, $885-917$ \\
\hline ISSN 0034-9631 (Impreso)
\end{tabular}
} 
la importancia en este sentido de que las acciones del mismo estén orientadas a asegurar la gestión democrática-; y 2) en conexión con esto, que como pasa históricamente con las "propuestas impuestas" (al menos en apariencia) desde lo gubernamental, se la deseche, desplace y/o reemplace con una política o emprendimiento ideológicamente opuesto como acto seguido a un cambio de gobierno. Otros de los miedos, sin tanto fundamento o anclaje en la propuesta en sí, a mi parecer, se relacionan con la postura anteriormente expuesta respecto de lo testimonial: ¿cómo articular un museo de la memoria desde el punto de vista de la representación y la verdad? Vezzetti comparte con Sarlo lo que podríamos definir como el problema de la intransferibilidad de la experiencia y en consecuencia de la memoria. ${ }^{28}$ Pero, aquí se entiende que si bien Vezzetti coincide en algunos puntos con Sarlo, también se explicitan diferencias. En primer lugar, el hecho mismo de tratar el tema de la ESMA abiertamente y luego, el pensar que la discusión y decisiones a tomar deben ser una responsabilidad de todos y no de un sector (llámese gobierno, académicos, sectores inmediatamente implicados, organismos de Derechos Humanos). Ésta es una diferencia en la interpretación del poder de gestión. Dice Vezzetti: "La mejor memoria es la que encarna en la cultura y en la vida social y política de una comunidad" y luego agrega en relación al tema de la subjetividad testimonial: "Es cierto que una intervención sobre la memoria social como la proyectada no puede prescindir de quienes han sido sujetos y agentes destacados del trabajo de rescate y reparación del pasado que se pretende conjurar". Finalmente, Vezzetti sostiene que es al Estado que le corresponde gestionar el consenso a través de sus políticas, garantizando el debate público.

Aunque todavía vigente la discusión, a más de cinco años de puesto en marcha el proyecto de expropiación y de instauración del "Espacio para la Memoria", en su

la acción comenzó con la Ley 392, aprobada por la Legislatura de la Ciudad de Buenos Aires en junio del 2000 (<www.institutomemoria.org.ar>), bajo otro gobierno con diferente sello político.

${ }_{28}$ Sería interesante conectar este punto de lo intransferible e irrecuperable y/o inenarrable con dos planteos: por un lado, con la noción de Emmanuel Levinas de lo "inmemorial". Remito al ensayo de Michael Bernard-Donals, "In Memoriam: Levinas, the Holocaust, and the Immemorial", en donde se trata justamente la disyuntiva entre la urgencia de hacer presente la memoria ("dar testimonio") y la misma imposibilidad de enunciar esa memoria o convertirla en lenguaje. Por otro lado, la idea de lo intransferible de la memoria al relato, como representación, se conecta también con lo que señala Walter Benjamin en "The Storyteller", ensayo que Sarlo cita e interpreta como una contradicción respecto de lo que percibe como el auge del testimonio (Tiempo pasado 29). La mirada nostálgica de Benjamin nos lleva a observar la deshumanización del siglo xx, que se hace bien perceptible en ese regreso silencioso de los combatientes de la Primera Guerra Mundial (Benjamin 84), el cambio en la relación del sujeto con la muerte (94) y sobre todo, la pérdida de esa condición artesanal del relato, en el pasaje del acto de contar (narrar como performance) a una narración que está fijada en letra, que pierde cierto aspecto humano (la voz, los gestos) y requiere de otros artilugios que no transmiten los mismos saberes, o al menos no de la misma forma. Para otra lectura de este ensayo de Benjamin respecto del discurso testimonial ver Beverley, Subalternidad 51, 107.

Revista Iberoamericana, Vol. LXXVII, Núms. 236-237, Julio-Diciembre 2011, 885-917 ISSN 0034-9631 (Impreso) 
funcionamiento actual, en manos de un Ente Interjurisdiccional tripartita, ${ }^{29}$ y en lo proyectado para su futuro. Los dos primeros miedos de la intelectualidad tanto como de la opinión pública llegan a un impasse hasta ver qué pasa durante la gestión de futuros gobiernos, sobre todo si los mismos son opositores del actual, de Cristina Fernández de Kirchner, según parecerían anticipar las elecciones de junio de 2009. De todas formas, se anticipa por parte del gobierno, los dirigentes y los medios que el predio estará en pleno funcionamiento antes del término de esta gestión. En las implementaciones vigentes, además, según se verá en el próximo apartado, éste no parece un espacio que se haya expropiado a la Armada como un acto arbitrario y vengativo para dejarlo simbólicamente morir, inutilizándolo; tampoco se trata de un "museo" donde desfilamos por escaparates silenciosos, ni donde se representa morbosamente el pasado, sino que se trata de un lugar donde se dan varios tipos de prácticas, sin duda testimoniales, que denotan poder de gestión en una cultura que de a poco aprende a vivir con aspectos tan inexplicables de su historia que, aunque actualmente comprobados, puestos en el marco de un relato de ficción y descontextualizados, quizás no resultarían siquiera creíbles.

\section{Alternativas testimoniales: Gestiones de la Memoria “A PUERTAS abiertas”}

Más allá de los debates específicos sobre la memoria y sus lugares asignados, ya sean éstos dados dentro del plano académico, jurídico, político-sectorial o en el espacio público en general, se podría decir que la sociedad argentina (al igual que otras con similares historias traumáticas) se bate en un dilema. Por un lado, se presenta la necesidad de seguir produciendo testimonio e instaurando fechas, espacios y mojones conmemorativos, tal vez sin detenerse en un análisis crítico y sin lograr que se profese la justicia, congelando así la memoria en formas que paradójicamente llevan al olvido. ${ }^{30}$

${ }^{29}$ En los medios se ha difundido la percepción del Espacio como un ente bipartita (Estado-organismos de DH), debido a que al ordenar su desalojo y restituirlo a la Ciudad de Buenos Aires, en marzo de 2004, en efecto se creó una Comisión Bipartita. Sin embargo, se trata de una estructura más compleja. El Ente está conformado por: un Directorio (Organismos de DH), un Consejo Asesor (integrado por ex detenidos de la ESMA) y un órgano ejecutivo (conformado por el Gobierno Nacional que está representado por el Archivo Nacional de la Memoria, el de la Ciudad y un representante del Directorio). Así, el Directorio del Ente tiene a su vez representación de los Organismos de DH, del Consejo Asesor y del órgano ejecutivo. Por otra parte, el Instituto Espacio para la Memoria está conformado por organismos diversos. Entre ellos: Servicio Paz y Justicia, Buena Memoria Asociación Civil, los poderes ejecutivo y legislativo de la Ciudad Autónoma de Buenos Aires, la Fundación Memoria Histórica y Social Argentina, Madres y Abuelas de Plaza de Mayo, Herman@s de Desaparecidos por la Verdad y la Justicia, H.I.J.O.S., entre otras.

${ }^{30}$ En el artículo que hemos citado de Hugo Vezzetti se hace referencia a las declaraciones del ex presidente Duhalde que llevan a asociar la propuesta del Museo "como un monumento en medio de un cementerio", imagen extrema, pero muy ilustrativa de lo que pasa cuando asociamos la memoria con un pasado que pertenece a los muertos, que es justamente la finalidad opuesta a la que debería tenerse respecto de los

Revista Iberoamericana, Vol. LXXVII, Núms. 236-237, Julio-Diciembre 2011, 885-917 ISSN 0034-9631 (Impreso) 
O, por otro lado, aparece la tendencia a criticar la creación de esos mismos mojones conmemorativos por su "inmovilidad", bajo la idea de promover -aunque pareciera a veces que sólo nominalmente-, que circule y se analice esa memoria en sus múltiples manifestaciones sin fijarla en monumento. Ninguna de las dos posturas funciona en sí misma, pero la segunda alternativa muchas veces ofrece en su implementación el problema de delegar en un grupo específico la labor analítica, por lo cual ese grupo detentaría la autoridad para "aprobar" y luego recién difundir ciertas manifestaciones de la memoria, mientras que negaría otras por no considerarlas pertinentes a la historia nacional. Desde ese lugar de privilegio se ejercería un procesamiento, ya sea jurídico (lo que sería loable) o sólo concienzudamente crítico del pasado en un círculo selecto, perpetuándose así las prácticas tradicionales de escritura de la historia. Entiendo que tal es la postura que de alguna forma implícita o entre líneas propone Beatriz Sarlo en Tiempo pasado, temiendo de manera quizás válida el primer problema: el anquilosamiento de la memoria sin el pertinente análisis crítico y sin transferencia efectiva a las próximas generaciones. Sin embargo, considero que lo riesgoso de la segunda opción consiste en que la función primero analítico-interpretativa y luego didáctica se deposite únicamente en un grupo selecto que desplace a los protagonistas o quite voz y autoridad a quien vivió los hechos traumáticos en carne propia.

Ni el archivo, ni el museo en su formato ortodoxo, ni la reducción a ciertas lecturas y juicios extra jurídicos, como el de la crítica académica, permiten que las versiones alternativas de la memoria histórica obtengan la resonancia que merecen al desplazar, alienar y desautorizar -ya sea desde los rótulos, ya sea desde intentos de ventrilocuismo o de enmascaramiento-, a sujetos que, por el contrario, necesitan que sus memorias sean integradas, reconocidas y respetadas desde sus lugares de emisión. En otras palabras, las voces que consideramos testimoniales (procedentes de víctimas sobrevivientes, hijos y demás familiares de desaparecidos, entre otros) nos recuerdan y reclaman que no se puede delegar en terceros el gestionar de la memoria. Apelan además a que la sociedad en su conjunto se haga cargo de una memoria que le compete de diversas maneras. Como señala Eduardo Grüner, con la política de la memoria sucede lo mismo que con la política a secas, "o la hacemos nosotros, o nos resignamos a soportar la que hacen los demás" (169).

¿Cuál sería una opción viable para tomar parte en las políticas de la memoria y para que múltiples voces encuentren su lugar en la historia? Quizás la respuesta esté en prestar atención e integrar analíticamente a la lectura mensajes como el siguiente, una pintada anónima en la ciudad de Rosario, a la entrada de El Pozo (uno de los centros de

“actos" y "espacios" de la memoria: que el pasado está presente y nos compete a todos como sociedad. Además, respecto de las paradojas que conlleva la memoria testimonial en sus diferentes formatos, remito a Langer (36-41), especialmente.

Revista Iberoamericana, Vol. LXXVII, Núms. 236-237, Julio-Diciembre 2011, 885-917 ISSN 0034-9631 (Impreso) 
detención clandestina más famosos e infames) y registrada para los visitantes virtuales en Lugares de memoria:

\author{
QUITAME DE ENCIMA BRONCE Y MONUMENTOS! SACAME DE ESTA \\ VITRINA

Vemos así que existen espacios, imágenes, prácticas que son "testimoniales" al inscribir una vivencia, a veces anónima, a veces de un colectivo o grupo que la firma, que denota injusticia social, exige atención, o al marcar un aspecto silenciado del pasado nacional. Son testimoniales en tanto tratan de hacer presente la memoria a todo el que quiera ver/oír y denuncian con urgencia la necesidad de justicia y esclarecimiento aunque se enmarquen en registros no documentales (al menos en el sentido tradicional del documento como prueba irrevocable). Además, aunque como se señalara, a veces son anónimos, son de todas maneras indudablemente subjetivos en tanto marcan una postura individual o de grupo que no quiere ocultar su lugar político de emisión aunque sí disfrazar su identidad específica, no con un sentido de engaño sino, por el contrario, para hacernos a todos partidarios de ese "yo". Éste es el carácter de muchos blogs y sitios de Internet que despliegan, a veces desde sus formatos en PDF o clips de YouTube,una galería que combina códigos de relato visual, escrito y mediático, del museo, del turismo y del tránsito (o del "surfear") por la red. Nos hacen estar ahí, presenciar, ser parte, al menos como receptores, del testimonio que ofrecen.

El mencionado Lugares de memoria del que se extrajo el texto de esta pintada o grafiti, ${ }^{31}$ permite, por ejemplo, visitar virtualmente el museo y la ciudad de Rosario focalizando en los lugares conmemorativos que atestiguan sobre la represión de la dictadura y sobre los reclamos de justicia a aquéllos que no están en la ciudad y no pueden concretamente recorrer las calles o entrar a los centros de detención clandestina

31 El Museo de la Memoria de Rosario, creado entre 1996 y 2002, funciona físicamente en la sede del II Cuerpo del Ejército, esquina de las calles Córdoba y Moreno, que fue expropiado por la Municipalidad de Rosario para dicho fin. A diferencia de lo que actualmente sucede con la ex ESMA, este Museo de la Memoria es más accesible desde todos los ángulos; por ejemplo, tiene un horario de atención al público fijo (de lunes a viernes de 9 a 17 y los sábados y domingos de 12 a 18 hrs.), sin la necesidad de pedir un turno o espacio en una visita guiada. El Museo ofrece exposiciones, charlas y conferencias relacionadas con la memoria, los Derechos Humanos y la historia argentina con especial enfoque en el periodo del terrorismo de estado. Tal vez esa accesibilidad tiene que ver con una cuestión de escala, o con su posición más periférica (respecto de Buenos Aires que siempre es el eje de atención nacional para bien y para mal) o con el hecho de que ha transcurrido más tiempo desde su fundación.

$\begin{array}{llll}\text { Revista Iberoamericana, Vol. LXXVII, Núms. 236-237, Julio-Diciembre 2011, 885-917 } & \text { ISSN 2154-4794 (Electrónico) }\end{array}$ 
ahora abiertos al público. Este sitio muestra las pintadas ciudadanas, esténciles o marcas urbanas, elementos dados en escraches y referencias a otras figuras relacionadas con la memoria popular, la historia rosarina en particular dentro del panorama nacional y la represión estatal, no limitada a los años de la dictadura. Como éste, son varios los espacios testimoniales y de memoria que se pueden recorrer en forma virtual y mediática, tanto desde lo físico como lo concreto. La creación y buen funcionamiento de estos sitios depende en general de una tarea colaborativa entre Estado u organismos gubernamentales, grupos de Derechos Humanos y participación de otros sectores de la ciudadanía, ya sea por iniciativa privada o colectivo-comunitaria. Así lo ejemplifica el caso particular de Rosario, cuya gestión exitosa está basada en la colaboración del gobierno municipal (representando a su vez al Estado nacional), grupos de Derechos Humanos, asociaciones civiles e instituciones educativas.

En este sentido, lo señalado por Vezzetti acerca del rol del Estado como garante de la participación ciudadana es importante, pero además se trata de incentivar a ese público a tomar la iniciativa porque, cuando las políticas parecen impuestas o fallan en involucrar a diversos grupos ciudadanos, todo queda en el olvido o se generan prácticas que no cumplen con los objetivos propuestos. Un ejemplo actual sería el "Parque de la Memoria" en la Ciudad Autónoma de Buenos Aires, inaugurado prematuramente en noviembre de 2007 por Néstor Kirchner (entonces presidente de la nación) y Jorge Telerman (intendente de Buenos Aires que terminó su breve gestión a sólo un mes de esta inauguración, en diciembre de 2007). A pesar de ser una iniciativa muy loable, generada como dice su página de la red (<http://www.parquedelamemoria.org $>$ ), como "un proyecto participativo y consensuado", con apoyo de grupos de Derechos Humanos y de la Universidad de Buenos Aires a nivel institucional, ${ }^{32}$ ha fracasado al no involucrar, por ejemplo, a grupos estudiantiles y a otros sectores más diversos, quedando a la deriva de las políticas y prioridades de la gestión de turno dentro del gobierno de la Ciudad al punto de alcanzar la mayor ironía: que nadie recuerde que existe (aunque en construcción, ya está inaugurado y supuestamente abierto al público) o dónde queda el "Parque de la Memoria". Por supuesto, todavía es posible y muy deseable que esto se revierta al finalizarse las obras planeadas y que entonces cumpla con su función. ${ }^{33}$

${ }^{32}$ Como puede observarse en la Ley $\mathrm{N}^{\circ} 46$ de la Legislatura de Buenos Aires que determina la creación de la Comisión pro-Monumento, dicha comisión está constituida mayoritariamente por miembros de la gestión política de turno, cualquiera que ésta sea (once diputados elegidos proporcionalmente a los bloques representados en la Legislatura, cuatro funcionarios designados por el jefe de gobierno porteño, el vicepresidente primero de la Legislatura, pero un sólo miembro de Derechos Humanos y otro único miembro representando a la Universidad de Buenos Aires), lo que pone al proyecto claramente a la deriva de los cambios político-electorales ( $<\mathrm{http}$ ://www.parquedelamemoria.org.ar $>$ ).

33 Cito la página del sitio (en la red), donde se explica los fines del proyecto: "Este espacio no pretende cerrar heridas que no pueden cerrarse ni suplantar la verdad y la justicia, sino ser un testimonio y un homenaje a las personas cuyas vidas quiso borrar un Estado que violó los derechos más elementales".

\footnotetext{
Revista Iberoamericana, Vol. LXXVII, Núms. 236-237, Julio-Diciembre 2011, 885-917
ISSN 2154-4794 (Electrónico)
} 
Un año y medio después de su apertura oficial, el Parque se hallaba cercado por un alambrado, su acceso cerrado con candado (aunque el cartel anunciara lo contrario) y sólo accesible a una mirada poco participativa, desde afuera. Desde 2010, sin embargo, existen motivos para ser optimistas ya que el Parque está finalmente abierto, con una agenda que incluye concursos de urbanística, visitas guiadas y acceso a un importante banco de datos sobre desaparecidos.

Acontinuación propongo, entonces, entrar y explorar en más detalle el rol testimonial delEspacio para la Memoria (Ex ESMA), en su estado actual, observando en la experiencia de la visita su función en la promoción de una toma de conciencia de la necesidad de apropiación de la historia por parte del público, en el sentido de reconocer nuestra responsabilidad ciudadana de recordar, de mantener activa la memoria, instruyéndonos para educar, a su vez, a las próximas generaciones. Además, en su función testimonial se verá cuán ineludible es que la ficción (como incursión de lo imaginativo) permee las narrativas que se van componiendo, siempre subjetivamente, del lado del visitante, espectador, transeúnte. Este lugar se ha convertido, en Argentina, en la materialización misma del controversial espacio que en la construcción democrática ocupa la memoria de momentos no precisamente heroicos para la Nación, pero tal vez sí en los actos de resistencia y supervivencia de quienes padecieron la detención ilegal. Abramos la puerta...

ESPACIO PARA LA MEMORIA

The location authenticates the narrative, embodies it, makes it real, to the point where it threatens to re-engulf those who come to tell and to listen.

Hirsch y Spitzer 272

En un ensayo donde se narra la experiencia del regreso de los padres de Marianne Hirsch a su ciudad de origen, la visita al gueto, evocando el peligro amenazante del campo de concentración en el momento de salida al exilio, los autores -Hirsch y su esposo, Leo Spitzer, quien es la voz de dicho discurso ensayístico- reflexionan en una especie de doble testimonio (el de los padres que cuentan y el de ellos que escuchan y experimentan por primera vez el estar allí) sobre el peso significativo del espacio físico donde se ha corporizado la experiencia traumática, por un lado, y por otro, que da forma real a una historia escuchada o leída y que por ende también reside, mediada, en la memoria de las generaciones que no vivieron ni una posible etapa "feliz" del lugar, ni el momento político-histórico que causó su derrumbe. Y, por lo tanto, tampoco sufrieron

Pueda ser que al concluirse las obras y tras una probable reinauguración que dé visibilidad al gobierno de turno, el parque cumpla plenamente la función conmemorativa y testimonial para la que se lo destinó.

ISSN 0034-9631 (Impreso) 
en carne propia la experiencia traumática (esto es a lo que los autores denominan "postmemoria"). ${ }^{34}$ Para quien vivió los hechos, el lugar trae una repetición, de alguna manera revive la experiencia. Para quienes nunca han estado allí, pero saben o imaginan por la mediación de un relato lo que sucedió, el espacio físico y su experiencia dan dimensión real y un grado de autenticidad a ese relato previo. ${ }^{35}$

Estamos en el lugar donde se corporiza una parte importante y traumática del relato histórico de Argentina que hasta hace unos poco años yacía en la zona del tabú, de lo silenciado. No más de quince personas se agrupan cerca de una de las maquetas informativas, con el edificio Cuatro Columnas en el fondo, alrededor de la guía, quien se presenta e invita a que su audiencia haga lo mismo. No todos lo hacen, pero de los que se animan se descubren intereses múltiples: escribir una nota para un diario del interior, una tesis, el simple interés de conocer más sobre la historia (actitud muy plausible) y hasta el turismo (por supuesto, en el caso de extranjeros). Por otra parte, como si fuera difícil enfrentarse solo a ese espacio cargado de terror, la mayoría ha venido acompañado de un amigo, su mamá, una hermana o ha traído a toda la familia. Sabrina, la guía, nos conduce, solícita y experta, por la versión de la historia que ha estudiado para ejercer su trabajo; una versión difícil y llena de huecos, formada a base de retazos de testimonios, algunos de los cuales podemos leer en las maquetas. Durante la visita, que se alarga todo lo que la inquietud lo requiere, ella se muestra con la mejor predisposición a pensar, responder y analizar cada una de las posibles (y disparatadas en muchos casos) ocurrencias y comentarios. La experiencia es una práctica de reflexión colectiva, de ejercicio de la memoria y narración de la historia de una manera indudablemente interactiva. Quizás por ello, al término de la visita y en una charla más informal, la guía reconoce que su

${ }^{34}$ Hirsch y Spitzer definen "post-memoria" como una relación mediada con un 'mundo de ayer' que se ha perdido, que esa generación misma ha heredado de sus padres y abuelos, pero no ha vivido (Hirsch 256). Ese 'mundo de ayer', sin embargo no es el del trauma sino que es un momento feliz inmediatamente anterior y por eso provoca un tipo de nostalgia. El argumento y teorización en torno a la nostalgia no será abordado aquí por no relacionarse con nuestro planteo. Respecto de la pos-memoria, Beatriz Sarlo también se refiere a este concepto al abordar el tema de los testimonios de hijos de desaparecidos y lo "discute", en parte utilizando como ejemplo argumentativo la película Los rubios (2003) de Albertina Carri (Tiempo pasado 126-57). No me detendré aquí en esto, pero vale decir que es discutible la "lectura" de Los rubios en relación a Hirsch, dado que a Carri lo que le falta es precisamente el relato que sustentaría su pos-memoria (el relato de sus padres) y de allí el problema identitario. También es discutible que la idea de pos-memoria únicamente refiera a lo íntimo, a espacios que tienen que ver con experiencias más privadas y no sea aplicable como tal a los espacios conmemorativos (Sarlo, Tiempo pasado 126).

35 Esta idea no sólo se basa en el trabajo de campo y experiencia personal de Marianne Hirsch y Leo Spitzer, sino que proviene del campo literario: de la lectura específica de un pasaje de la novela de Toni Morrison, Beloved. Hay que aclarar aquí que en la comparación con lo que describiré (la visita a la ex ESMA) existen, como se verá, algunas diferencias tanto con el modelo que inspira a Hirsch y Spitzer (la novela de Morrison) como con sus experiencias como hijos o generación de pos-memoria.

Revista Iberoamericana, Vol. LXXVII, Núms. 236-237, Julio-Diciembre 2011, $885-917$
ISSN 2154-4794 (Electrónico) 
trabajo, aunque remunerado, no sería posible sin un grado de compromiso y que la carga emotiva que conlleva el poner en acto el pasado del lugar no le permitiría realizarlo con la frecuencia en que se hace aquello que se puede automatizar.

Sí, hay mucho de emotivo en esta experiencia, algo que nos toca muy de cerca aun si no estamos directa o evidentemente conectados (por no tener un familiar desaparecido, por ejemplo) con lo que pasó en la ESMA. Cabe notar, sin embargo, que a diferencia de lo que sucede con Hirsch y Spitzer en la visita a Czernowitz o al campo de concentración en otro de sus artículos (en Kuhn y otros 135-54), no hay nada aparentemente afectivo que nos ate al lugar que visitamos, y por supuesto nada que revista al espacio con una luz de pasado positivo más allá de pensar en la finalidad a la que originalmente estaba destinado era la de educar a quienes defenderían la Nación y por ende "nos" defenderían (finalidad no cumplida sino todo lo contrario). En segundo lugar, existe otra diferencia: tanto quien habla y explica sobre el lugar (la guía) como los visitantes que escuchan e intervienen con preguntas, en este caso, carecen de una experiencia directa de los hechos acontecidos; en el caso de los visitantes, ni siquiera hemos recibido el relato de la voz (en su tono, timbre, gesticulación) de un testigo directo. En este sentido, estamos reviviendo por completo una memoria de otros, en todas sus facetas, traumática, sin nada que se pueda rescatar más allá del hecho de que algunos hayan sobrevivido para contarlo y de que podamos aprender para que no se repita. De alguna manera, a pesar de ello, como resultado de la experiencia los visitantes nos convertimos también en testigos mediante este "acto de presencia" (Derrida 38). Esto es muy relevante si tenemos en cuenta la trasmisión generacional, ya que tanto la guía como la mayoría de los visitantes nos ubicamos por nuestra edad más cerca de los "hijos" o de la pos-memoria que de quienes vivieron los hechos de primera mano y esto va a ser un hecho cada vez más significativo a medida que pase el tiempo.

Sin embargo, entra en juego aquí un componente crucial en la trama que el visitante recompone. Además del relato que va construyendo la guía y los visitantes con sus preguntas (como se mencionó, en muchos casos, bastante imaginativas), un elemento clave en esta actualización de la memoria que se lleva a cabo en el predio es la presencia de palabra misma de los detenidos sobrevivientes. Esos fragmentos de testimonios que aparecen como leyendas descriptivo-informativas son lacónicos y a la vez fuertemente representativos del trauma y del dolor experimentado. Se encuentran alrededor y adentro del Casino de Oficiales, explicando sintéticamente lo que pasaba en cada sector o dando una breve y puntual nota sobre la experiencia subjetiva. Es en "Capucha" donde las voces de los sobrevivientes se hacen más presentes: Lila Pastoriza, Graciela Daleo, Andrés Castillo, Ana María Martí y Sara Osatinsky ${ }^{36}$ son algunos de

${ }^{36}$ Víctimas sobrevivientes de la detención ilegal, secuestro y tortura en la ESMA, en la actualidad se trata de figuras reconocidas como activistas de Derechos Humanos, cuyo aporte testimonial ha sido fundamental

Revista Iberoamericana, Vol. LXXVII, Núms. 236-237, Julio-Diciembre 2011, $885-917$
ISSN 0034-9631 (Impreso) 
los testigos-sobrevivientes que rememoran lo que allí vivieron con la brevedad de lo que no se quiere tal vez recordar por el dolor que significa articular esa memoria en palabras. Las palabras son concretamente una traza, una marca de la imposibilidad de representar lo vivido en ese espacio semi-vacío, pero a la vez tan lleno de significado. ${ }^{37}$

Dentro del Casino de Oficiales, los espacios se designan con apodos que de manera eufemística ("Huevera" por "sala de torturas"), metafórica ("Pecera" por el lugar donde algunas de las víctimas eran forzadas a realizar trabajos de inteligencia bajo la vigilancia continua, detrás de un tabique de vidrio, de sus captores), siempre simbólica ("Capucha" y "Capuchita" porque se llegaba y se residía encapuchado, además de ser éstos los entretechos o altillos del edificio), buscan nombrar algo anormal, una experiencia que roza la del sueño pesadillesco. En su funcionamiento como centro clandestino de detención, maternidad ilegal, robo de bebés y lugar de exterminio (o campo de concentración) los nombres servían como un instrumento más para encubrir, intentando cegar todo posible vislumbre de lo que ocurría, disfrazando morbosamente de normalidad los actos aberrantes de tortura y desaparición (la muerte encubierta bajo el concepto del final "traslado"). Aunque los espacios están prácticamente vacíos a excepción de las maquetas o carteles con sus leyendas informativas ("tal y como los dejaron los militares al entregar el predio" nos señala la guía), se va descubriendo lo que habría y pasaba en cada lugar. La guía describe cómo eran los movimientos dados en el Casino de Oficiales, qué pasaba en cada sector, las modificaciones efectuadas al edificio ante la inspección y visita de la Comisión Interamericana de Derechos Humanos en 1979, entre otros aspectos del funcionamiento clandestino del predio. Cada espacio se presta a múltiples especulaciones por parte de los visitantes, algunas de ellas articuladas en preguntas (que en general no tienen respuesta posible, al menos de parte de los allí presentes), lo cual determina que la información provista por los fragmentos testimoniales de los sobrevivientes y el discurso de la guía se combina con lo que cada sujeto visitante imagina, construyendo un relato y una memoria nueva y particular del lugar, una perspectiva de la historia mediada por la información recibida tanto como por las impresiones subjetivas, con mucho de imaginativo, acerca del espacio.

Al llegar al primer altillo ("Capucha"), donde el clima entre los visitantes se vuelve por demás lúgubre en tanto se observa el grado de deshumanización al que eran sometidos los detenidos, se relata una anécdota (obtenida a su vez de lo narrado por un

en los juicios a represores y en la apertura de espacios conmemorativos. Es posible ver en la red, por ejemplo, parte de sus testimonios en una de las causas ya digitalizadas. Véase $<$ http://www.derechos.org/ nizkor/arg/informes.html>.

37 Sobre la teatralidad del espacio, que aún en su desnudez está cargado de representación (en los varios sentidos de la palabra) y que conduce a una respuesta del espectador/visitante, remito al casi clásico ensayo de Peter Brook, particularmente al experimento que menciona en las páginas 24-25. Agradezco a Paola Hernández (Universidad de Wisconsin-Madison) la ayuda bibliográfica.

\footnotetext{
Revista Iberoamericana, Vol. LXXVII, Núms. 236-237, Julio-Diciembre 2011, 885-917
ISSN 2154-4794 (Electrónico)
} 
testigo sobreviviente): un día en que un guardia o represor de turno les "dio permiso" de contar chistes a los detenidos/secuestrados (lo que en el contexto equivale a decir que "les ordenó contar chistes", lo que es en sí una imagen llena de anormalidad), el primer chiste que surgió era uno imposible, tanto como la situación misma de contar chistes y reírse en esas circunstancias: un chiste contado con mímica para una audiencia de encapuchados. La guía destaca entonces cuál es el objetivo último de su tarea. Como la de los testigos que cuentan su experiencia desde lo personal, el propósito no es aquí la narración de la macrohistoria que se pretende unívoca, sino el acceso a la vivencia de un grupo al que le tocó estar del otro lado de un poder detentado inhumana y despóticamente: "Lo que nos interesa son esos pequeños actos [de resistencia] de los detenidos", nos aclara. Y los que estamos allí comprendemos que precisamente son "esos pequeños actos" los que hicieron posible que hoy, en este lugar, accedamos a una parte, antes oculta, de la historia nacional.

La visita termina en el regreso al edificio Cuatro Columnas, donde sí es posible sacar fotos como en los exteriores del predio. Allí se encuentra documentación selecta y muy valiosa: diarios y revistas de época con artículos que demuestran el grado de perversión del sistema represivo, así como publicaciones más actuales que reflejan la lucha por recuperar la memoria y lograr a través de ello un grado importante de justicia, por lo menos en lo que hace al relato histórico nacional.

Finalmente, cabe agregar respecto del predio que se tiende a asociar este Espacio para la Memoria principalmente con el edificio del Pabellón Central o lo que llamamos "Cuatro Columnas" y con el Casino de Oficiales, los dos lugares abiertos a la visita guiada por el momento y que representan lo más sombrío de la historia: una fachada de escuela tras la que se esconde la detención clandestina, la tortura, el robo de bebés, la desaparición de personas. Sin embargo, este plan de recuperación y re-significación memoriosa del espacio supone la incorporación de otros edificios del predio al acceso público como parte del Instituto Espacio para la Memoria: la Enfermería, el Pabellón Coy, el taller de Automotores y la Imprenta. Además, hay un pabellón que está asignado a "Familiares de Desaparecidos y Detenidos por Razones Políticas"(ex "Pabellón Beta"), otro al Instituto de Políticas Públicas en Derechos Humanos del Mercosur (ex- "Comedor") y la "Casa de Nuestros Hijos, la Vida y la Esperanza", asignado a las Madres de Plaza de Mayo Línea Fundadora (ex "Pabellón Alfa"). Por último, no se puede soslayar la importante presencia del ECuNHi, Espacio Cultural "Nuestros Hijos" de las Madres de Plaza de Mayo. Actualmente bajo la dirección de Teresa Parodi, el ECuNHi no sólo está abierto al público, sino que es la zona más activa en todo sentido dentro del predio, ofreciendo una variedad de actividades culturales como conciertos, talleres y eventos diversos, orientados a mucho más que la preservación de la memoria. La agenda del ECuNHi tiene varios objetivos, pero de ellos el más ambicioso quizás sea la creación de una Universidad de Artes y Oficios que, en palabras de su directora, Teresa

\footnotetext{
Revista Iberoamericana, Vol. LXXVII, Núms. 236-237, Julio-Diciembre 2011, 885-917
ISSN 0034-9631 (Impreso)
} 
Parodi, "dé respuesta concreta de capacitación a la población de la ciudad, del país y del mundo, y que se caracterice por poseer contenidos académicos de excelencia". ${ }^{38}$

¿De quiÉn, LA historia? Aprehendiendo...

\begin{abstract}
Nuestras clases dominantes han procurado siempre que los trabajadores no tengan historia, no tengan doctrina, no tengan héroes y mártires. Cada lucha debe empezar de nuevo separada de las luchas anteriores: la experiencia colectiva se pierde, las lecciones se olvidan. La historia aparece así como propiedad privada cuyos dueños son los dueños de todas las otras cosas. Esta vez es posible que se quiebre ese círculo.
\end{abstract}

Rodolfo Walsh, 1970

Son muchas las formas en que las experiencias de la historia se manifiestan y mediante las cuales nos posicionamos para interpretarla y entenderla. De alguna manera, hemos hablado aquí de "prácticas de historización", ${ }^{39}$ en las que el pasado de la etapa de dictadura y terrorismo de Estado, aunque no tan lejano (o quizás precisamente por no estar tan lejano) se recrea y se integra al presente de una manera todavía conflictiva, pero que demuestra con determinación la voluntad de no olvidar. El discurso testimonial es una de esas formas o prácticas de historización que parten de la propia vivencia de la historia, generalmente traumática, que se vuelve presente por el acto de recordar y luego narrar. Por eso, comenzamos hablando de los desafíos que justamente postula el testimonio, como discurso jurídico, como narrativa fijada en letra, como memoria que se actualiza al representar en palabras una experiencia que si bien es urgente nombrar, también es imposible por el horror y dolor que conlleva. Así, intricadamente ligada a la verdad, pero simultáneamente a la ficción, la historia del testigo, en lo personal y en lo colectivo, denuncia y nos apela a actuar, a la vez que no podemos pedirle pruebas más allá de la prueba misma que es ese acto presencial. La subjetividad, la inevitable ficción o el relleno imaginativo de los baches siempre dados en la memoria (no importa cuán reciente la experiencia sea), la ambivalencia entre la verdad factual y la personal (dada por una vivencia única e irrepetible), son algunos de los puntos que hacen de esa manifestación particular de la historia que es lo testimonial, una zona de pasiones, de conflicto, pero además de oportunidad: de llegar a la justicia, de establecer alianzas, o un diálogo productivo y, sobre todo, una oportunidad de conocimiento.

${ }^{38}$ Véase "El Proyecto de las madres de la Plaza de Mayo" en $<$ http://www.nuestroshijos.org.ar/general. php?id=Institucional $>$.

39 Al hablar de "prácticas de historización" me refiero aquí a la definición que ofrece Federico Lorenz, siguiendo a su vez a Rosana Guber (Jelin, Conmemoraciones 55).

Revista Iberoamericana, Vol. LXXVII, Núms. 236-237, Julio-Diciembre 2011,
ISSN 0034-9631 (Impreso) 
Para que la memoria desde lo testimonial llegue a una zona de oportunidad, habría que promover su pasaje de un estadio subjetivo y personal a uno colectivo, para que se ejerza así el poder democratizador que da el conocimiento $\mathrm{y}$, a su vez, posibilite un acercamiento crítico-interpretativo por parte del cuerpo social. Habría que evitar, además, un congelamiento, ése del archivo que conserva, pero en el estado fijo de una letra que termina tan bien guardada que queda oculta a los ojos de la sociedad, anquilosada en el tiempo. Necesitamos tomar en nuestras manos y hacernos cargo de la gestión de la historia, aceptando el reto como una responsabilidad propia para la construcción de un verdadero espacio democrático que involucre a la sociedad civil en su conjunto con sus diversas opiniones e incorporando al presente la memoria como un ejercicio permanente. Considero que para que eso sea posible es vital tener en cuenta las formas populares y alternativas al testimonio jurídico y/o literario (en el sentido de plasmado en letra y no sólo de letra artística), en los que la memoria se expresa, ya sea en la recurrencia a otros registros documentales (muestras fotográficas, por ejemplo) o desde ópticas marcadamente ficcionales (novela y telenovela), ya sea mediante un gesto de protesta como un escrache, una murga o una pintada, ya sea como producción mass-mediática, sitio de la red o emplazamiento conmemorativo en un lugar de amplia circulación donde además se exponga al público a eventos culturales relacionados con esa historia conmemorada. Así, se ha observado en este trabajo cómo el Espacio para la Memoria en la ex ESMA constituye una forma testimonial donde la práctica de la visita nos hace sujetos activos en la construcción del relato histórico nacional. En este sentido, en "el país del no me acuerdo", toda ayuda-memoria se debería agradecer para que los reclamos e inseguridades del diario vivir no hagan recaer a la sociedad civil en la repetición de esos ciclos de represión y violencia que caracterizaron a una buena parte de la relativamente corta historia argentina, sobre todo en el siglo xx. Pasados los veinticinco años de haber recuperado el Estado de Derecho en Argentina, asumimos y queremos creer que el vaticinio esperanzado de Rodolfo Walsh (entre otras cosas, pionero de la escritura testimonial $)^{40}$ que se propaga hoy en la Internet, es una realidad: que el

40 Rodolfo Walsh (1927-¿1977?), escritor, periodista e intelectual argentino. Tal vez su biografía ejemplifica dramáticamente el carácter pasional de lo testimonial. Un día después de escribir "Carta abierta a la Junta Militar" (actualmente en la red: <http://www.literatura.org/Walsh/rw240377.html>), fue desaparecido por la dictadura. Datos aportados por algunos testigos-sobrevivientes, como Lila Pastoriza y Andrés Castillo (antes mencionados por la presencia de sus voces en el Espacio para la Memoria), indicarían que podría haber estado detenido ilegalmente en la Escuela de Mecánica de la Armada antes de ser ejecutado/"trasladado" (ver <http://www.derechos.org/nizkor/arg/causa13/casos/caso484.html>). En su obra se destacan los textos de corte periodístico-testimonial Operación Masacre (1957), ¿Quién mató a Rosendo? (1969) y El caso Satanowsky (1973, aunque escrito en 1958). Sobre su carácter pionero respecto de una escritura periodístico-testimonial (o "novela factual", "novela de no-ficción" entre otros rótulos dados desde la crítica argentina), cabría escribir otro trabajo, pero vale observar aquí, como ejemplo anecdótico de ello, que en Recuerdo de la muerte (1994), novela testimonial de Miguel Bonasso

\begin{tabular}{l} 
Revista Iberoamericana, Vol. LXXVII, Núms. 236-237, Julio-Diciembre 2011, $885-917$ \\
\hline ISSN 0034-9631 (Impreso)
\end{tabular} 
círculo en efecto se ha quebrado y en la medida en que aceptemos tanto los privilegios como la responsabilidad de ser todos y cada uno "propietarios" de la historia, la gestión democrática se hará cada vez menos tambaleante.

Finalmente, un testimonio, en sentido amplio, es aquéllo que comunica y hace presente figurativamente las imágenes de un pasado irrevocable, a veces fantasmagórico y terrible que muchos preferirían poder olvidar o que fuera mera ficción (en el sentido de "pura imaginación"), pero que por el contrario estamos en la obligación de reactivar para entender y aprender, para solidarizarnos con nuestros semejantes y emprender alianzas tanto concretas como simbólicas. Pero convengamos que estos ejercicios intelectuales (analizar, comprender, aprender) son posibles y actúan como actividades democratizadoras si y sólo si las diferentes versiones y verdades son respetadas, es decir, siempre y cuando se tome en su contexto y no se descarte, silencie, ni censure ninguna pieza de ese rompecabezas (Calveiro 14), perpetuamente incompleto, eternamente "en construcción", que hacemos presente como "nuestra" historia, desde una primera persona inclusiva, asumiéndola propia aun en lo que tiene de impropio.

APÉNDICE: ALGUNAS IMÁGENES ${ }^{41}$

\section{Buenos Aires}
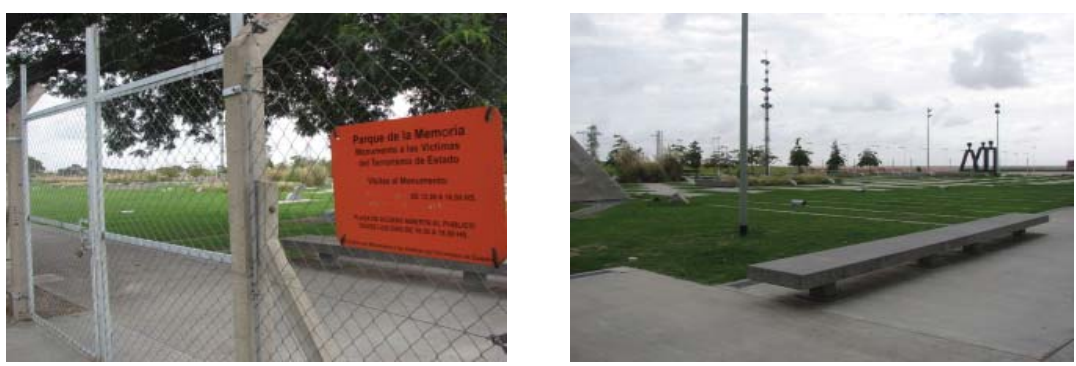

"Parque de la Memoria, Monumento a las Víctimas del Terrorismo de Estado" en la costanera, Ciudad Autónoma de Buenos Aires...en construcción. A pesar de que el cartel indica que está abierto (se lee: "visita al monumento de 12 a 16 hrs.", y más abajo: "Plaza de acceso abierta al público todos los días de 10 a 18 "; la foto fue tomada a las 14 hrs., un viernes), la puerta de acceso está cerrada con candado y sólo puede "visitarse" desde este lado del alambrado y tomar fotos por entre los agujeros romboidales de éste.

también conectada con los infames hechos de la ESMA, el primer epílogo refiere a Rodolfo Walsh como "maestro" de quien firma el texto (444), trazando así un linaje del género.

${ }^{41}$ Fotos tomadas por la autora de este artículo en febrero-marzo de 2009, a excepción de la última imagen que pertenece a "Lugares de memoria" del Museo de la Memoria de Rosario.

Revista Iberoamericana, Vol. LXXVII, Núms. 236-237, Julio-Diciembre 2011, 885-917 ISSN 0034-9631 (Impreso) 

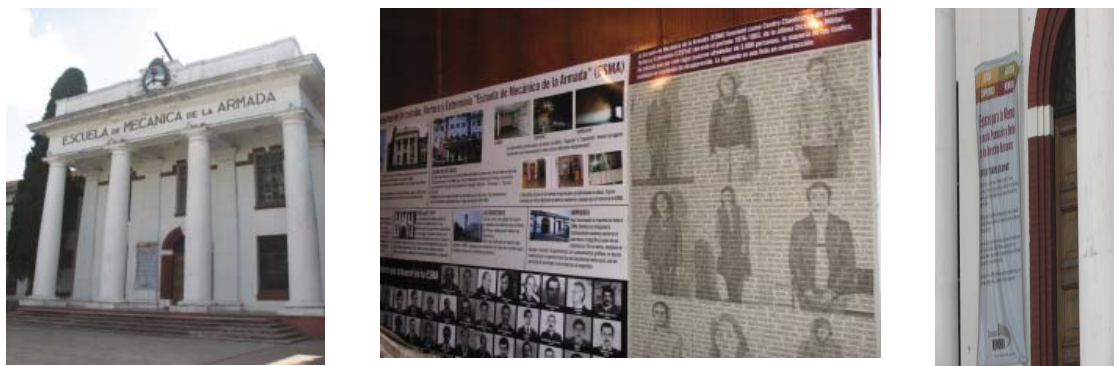

ESMA- Edificio "Cuatro Columnas”. Interior: póster de represores y desaparecidos. Detalle entrada: "Espacio para la Memoria y para la Promoción y Defensa de los Derechos Humanos".
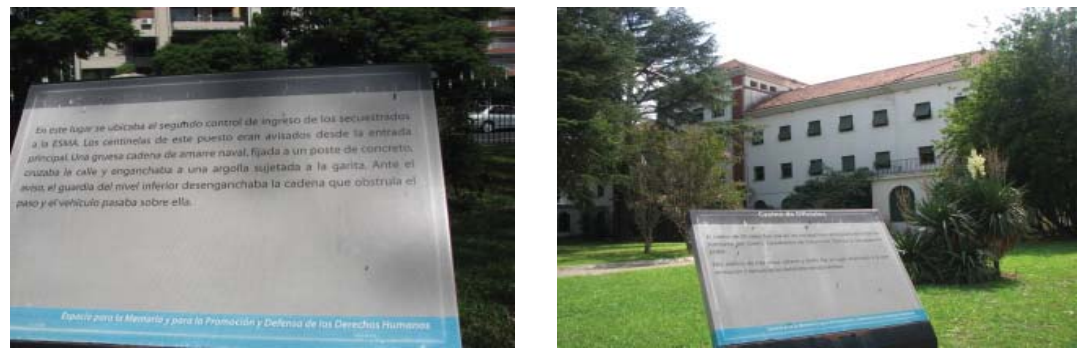

Fragmentos didáctico-testimoniales. Al fondo, el Casino de Oficiales.
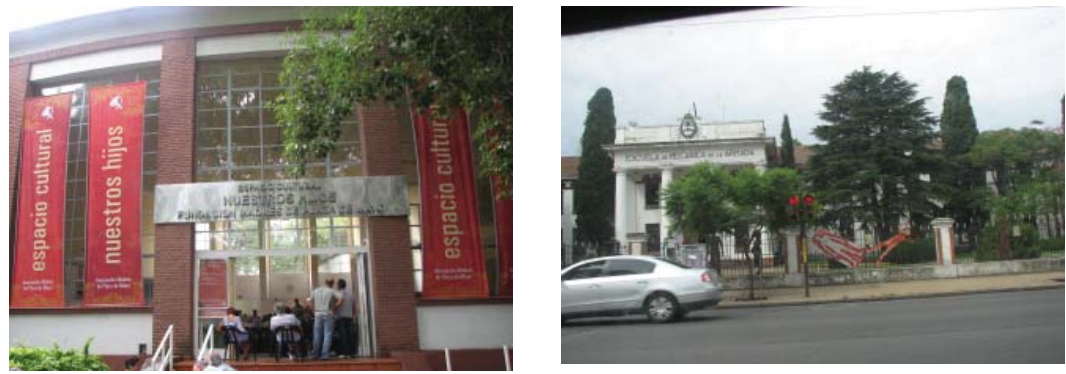

ECuNHi - Espacio Cultural Nuestros Hijos, dentro del predio del Espacio para la Memoria, durante un festival de chamamé, acceso libre y gratuito (febrero 2009). Al lado, fachada del predio desde la calle (Avenida del Libertador).

Revista Iberoamericana, Vol. LXXVII, Núms.
ISSN 0034-9631 (Impreso) 
Otras imágenes:

Reclamo por la desaparición de Jorge Julio López: "SIN LÓPEZNOHAYNUNCAMÁS".

La pancarta remite al sitio de la Comisión Provincial por la Memoria (<http://www. comisionporlamemoria.org $>$ ).

La Plata, en calle 54, casi esquina 2.
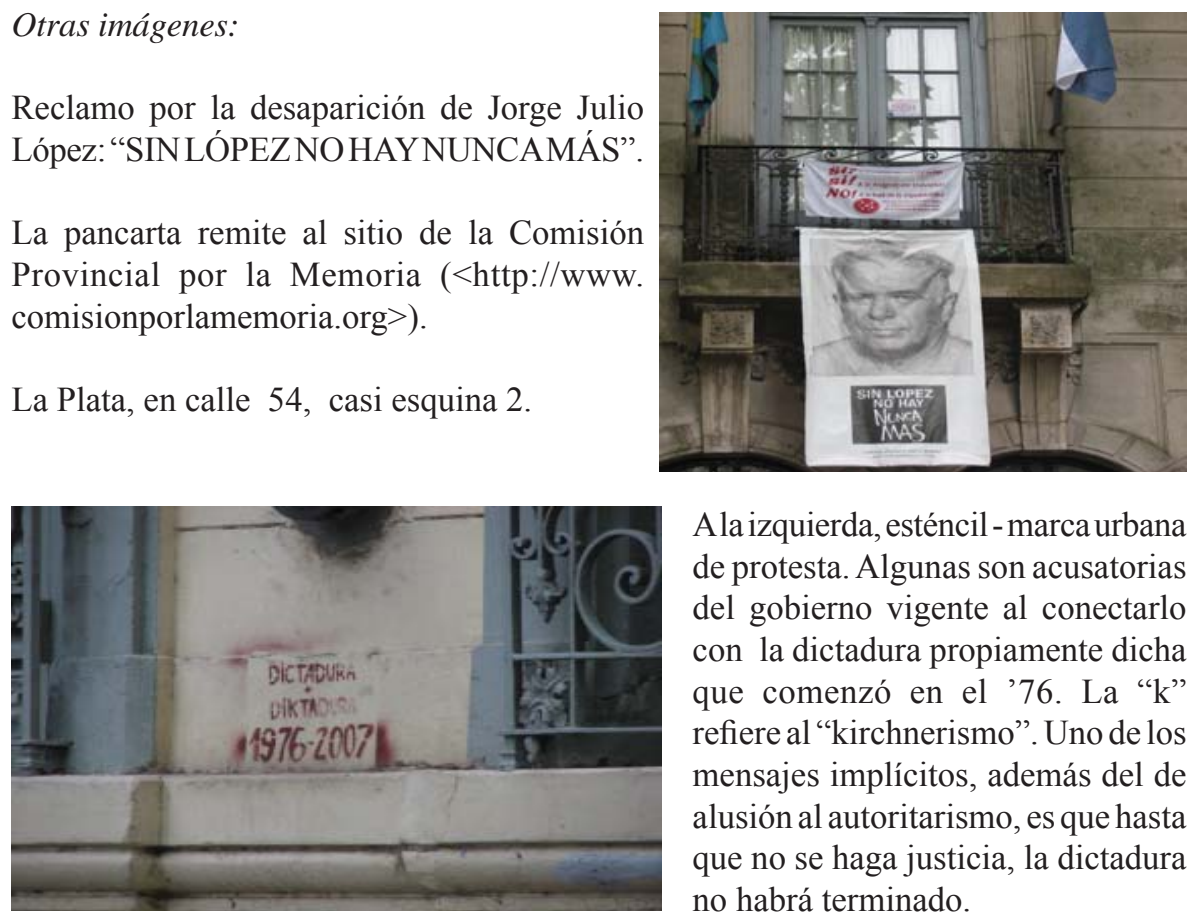

Ala izquierda, esténcil-marca urbana de protesta. Algunas son acusatorias del gobierno vigente al conectarlo con la dictadura propiamente dicha que comenzó en el '76. La " $\mathrm{k}$ " refiere al "kirchnerismo". Uno de los mensajes implícitos, además del de alusión al autoritarismo, es que hasta que no se haga justicia, la dictadura no habrá terminado.

Otros esténciles (la mayoría) en la ciudad de La Plata refieren al reclamo por la desaparición de López.

"Lugares de Memoria”, Rosario.

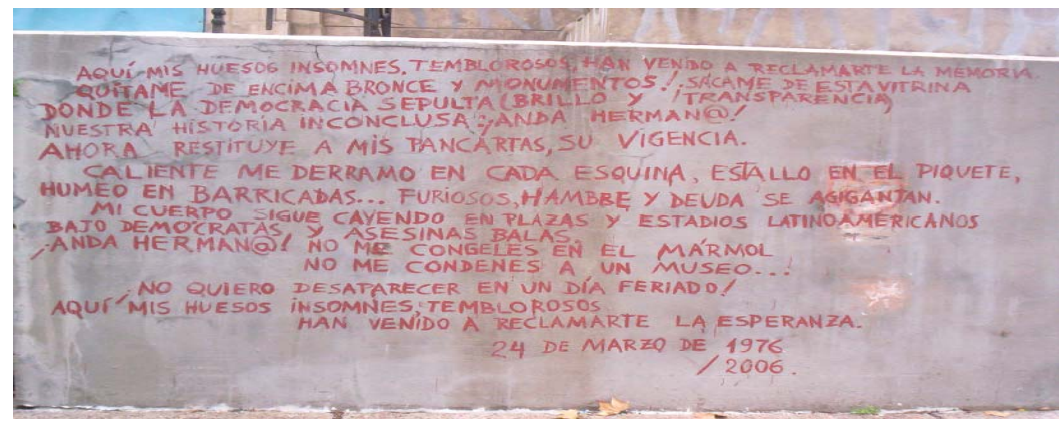

Pintada al lado de la puerta de entrada aEl Pozo, Rosario (<http://www.museodelamemoria. gov.ar/lugares-de-memoria.pdf $>$ ).

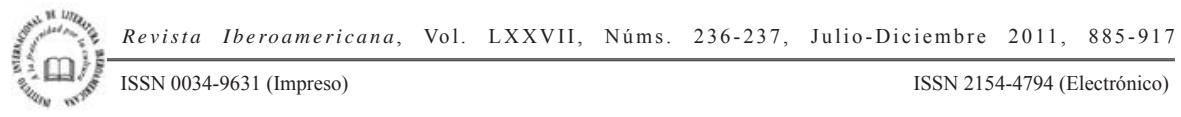




\section{BIBLIOGRAFÍA Y RECURSOS}

Abrevaya, Sebastián. "Para que los argentinos podamos volver a mirarnos la cara”. Página/12. 21 nov. 2007. <http://www.pagina12.com.ar/diario/ elpais/1-95012-2007-11-21.html>. 18 dic. 2008

Actis, Munú et al. Ese infierno: conversaciones de cinco mujeres sobrevivientes de la ESMA. Buenos Aires: Sudamericana, 2001.

Amar Sanchez, Ana María. "La ficción del testimonio". Revista Iberoamericana LVI/151 (1990): 447-61.

"La propuesta de una escritura (En homenaje a Rodolfo Walsh)". Revista Iberoamericana LII/135-136 (1986): 431-45.

El relato de los hechos. Rosario: Beatriz Viterbo, 1992.

Arditti, Rita.Searching for Life. The Grandmothers of Plaza de Mayo and the Disappeared Children of Argentina. Berkeley: U of California P, 1999.

Bal, Mieke y otros, eds. Acts of Memory: Cultural Recall in the Present. Hanover, NH: Dartmouth College, UP of New England, 1999.

Balderston, Daniel et al. Ficción y política. La narrativa argentina durante el proceso militar. Buenos Aires:Alianza; Minneapolis, MN: Institute for the Study of Ideologies and Literature, U of Minnesota, 1987.

Benjamin, Walter. Illuminations. Essays and Reflections. Nueva York: Random House, 2007.

Bergman, Miranda, etal. "Breaking the Silence”. Bridges of Power. Women's Multicultural Alliances. Lisa Albrecht, et al., eds. Filadelfia: New Society, 1990. 211-15.

Bernard-Donals, Michael. "In Memoriam: Levinas, the Holocaust and the Immemorial" Mosaic 40/1 (2007): 2-16.

Beverley, John. "The Margin at the Center". The Real Thing. Testimonial Discourse in Latin America. Durham: Duke UP, 1996. 23-41.

Subalternidad y representación. Madrid: Iberoamericana; Frankfurt am Main: Vervuert, 2004.

Bonaldi, Pablo Daniel. "Hijos de desaparecidos. Entre la construcción de la política y la construcción de la memoria". El pasado en el futuro: los movimientos juveniles. Elizabeth Jelin y Diego Sempol, comps. Buenos Aires: Siglo XXI, 2006. 143-84.

Bonasso, Miguel. Recuerdo de la muerte. Buenos Aires: Planeta, 1994.

Borrelli, Martín. "ESMA, espacio sin reconciliación”. <www.legislatura.gov.ar/ legislatura/191/images/Articulo\%20ESMA.doc>. 1 marzo 2009.

Braslvasky, Guido. "Kirchner y Cristina oficializaron la creación del Museo de la ESMA.

Diario Clarín. 21 nov. 2007.<http://www.clarin.com/diario/2007/11/21/elpais/p-00801. htm.> 16 dic. 2008.

Brodsky, Marcelo. Memoria en construcción: el debate sobre la ESMA. Buenos Aires: La Marca, 2005.

Revista Iberoamericana, Vol. LXXVII, Núms. 236-237, Julio-Diciembre 2011, 885-917 
Brook, Peter. The Empty Space. Nueva York: Atheneum, 1969.

Calveiro, Pilar. Política y/o violencia. Una aproximación a la guerrilla de los años 70. Buenos Aires: Norma, 2005.

Cohen, Stanley. States of Denial: Knowing About Atrocities and Suffering. Cambridge Polity; Malden, MA: Blackwell, 2001.

Crane, Susan, ed. Museums and Memory. Stanford: Stanford UP, 2000.

Da Silva Catela, Ludmila y Elizabeth Jelin, comps. Los archivos de la represión: documentos, memoria y verdad. Buenos Aires: Siglo XXI, 2002.

Derrida, Jacques. Demeure. Fiction and Testimony. Elizabeth Rottenberg, trad. Stanford: Stanford UP, 2000.

"Fichus. Frankfurt Address". Paper Machine. Stanford: Stanford UP, 2005. 164-181.

Forcinito, Ana. Memorias y nomadías: géneros y cuerpos en los márgenes del posfeminismo. Santiago de Chile: Cuarto Propio, 2004.

García Canclini, Néstor. Culturas Híbridas. Estrategias para entrar y salir de la modernidad. México: Grijalbo, 1989.

Gabeta, Carlos. Todos somos subversivos. Buenos Aires: Bruguera, 1983.

Grüner, Eduardo. La cosa política o el acecho de lo Real. Buenos Aires: Paidós, 2005.

Gugelberger, George M., ed. e intro. The Real Thing. Testimonial Discourse and Latin America. Durham: Duke UP, 1996.

Hirsch, Marianne y Leo Spitzer."'We Would Not Have Come without You': Generations of Nostalgia". American Imago 59/3 (2002): 253-76.

Huyssen, Andreas. Present Pasts: Urban Palimpsests and the Politics of Memory. Stanford: Stanford UP, 2003.

Jauretche, Ernesto. Violencia y política en los setenta. No dejés que te la cuenten. Buenos Aires: Pensamiento Nacional, 2000.

Jelin, Elizabeth, comp. Las conmemoraciones: Las disputas en las fechas "in-felices". Buenos Aires: Siglo XXI, 2002.

"The minefields of memory" NACLA Report on the Americas 32/2 (sept/oct 1998): 23-29.

Los trabajos de la memoria. Buenos Aires: Siglo XXI, 2002.

y Susana Kaufman (Comps.). Subjetividad y figuras de la memoria. Buenos Aires: Siglo XXI, 2006.

Kaufman, Alejandro. "Aduanas de la memoria. A propósito de Tiempo pasado de Beatriz Sarlo". Rayando los confines. <http://www.rayandolosconfines.com.ar/ critica kaufman.html>. 1 marzo 2009.

Kollmann, Raúl. "Seis de cada diez están de acuerdo. Encuesta". Página/12. 28 marzo 2004. <http://www.pagina12.com.ar/diario/elpais/1-33394-2004-03-28.html>. 10 feb. 2009.

Revista Iberoamericana, Vol. LXXVII, Núms. 236-237, Julio-Diciembre 2011, 885-917 ISSN 0034-9631 (Impreso) ISSN 2154-4794 (Electrónico) 
Kuhn, Annette y Kirsten Emiko McAllister, eds. Locating Memory. Photographic Acts. Nueva York: Berghahn, 2002.

Lafforgue, Jorge, ed. Rodolfo Walsh. Buenos Aires: Alianza, 2000.

Langer, Lawrence. Holocaust Testimonies. The Ruins of Memory. New Haven: Yale UP, 1991.

Levaggi, Nahuel. El fogón de la memoria. Historias de vida y de luchas de los '70 hasta hoy, rupturas y continuidades. Buenos Aires: Editorial El Colectivo, 2007.

Longoni, Ana. "Ana Longoni: 'No se soporta decir que los desaparecidos delataron'”. Entrevista por Juan Terranova. Perfil. 11 marzo 2007. <http://www.diarioperfil. com.ar/edimp/0167/articulo.php?art=132\&ed=0167>. 10 junio 2009.

Traiciones. La figura del traidor en los relatos acerca de los sobrevivientes de la represión. Buenos Aires: Norma, 2007.

Macón, Cecilia, coord. Trabajos de la memoria: arte y ciudad en la postdictadura argentina. Buenos Aires: Ladosur, 2006.

Marimón, Antonio. El antiguo alimento de los héroes. Buenos Aires: Puntosur, 1988.

Marlowe, Ángeles. "Siguiendo el juicio a los represores en Corrientes (crónicas desde la periferia)". <http://siguiendoeljuicio.blogspot.com/>. 24 marzo 2008.

Martín-Barbero, Jesús. "Between Technology and Culture: Communication and Modernity in Latin America". Cultural Agency in the Americas. Doris Sommer, ed. Durham: Duke UP, 2006. 37-51.

"Intervening from and through Research Practice: Meditations on the Cuzco Workshop". Cultural Agency in the Americas. Doris Sommer, ed. Durham: Duke UP, 2006. 31-36.

Martínez, Diego. "Graciela Daleo: 'Fisurar el muro de impunidad golpea el poder'”. Página/12. 16 dic. 2007. <http://www.pagina12.com.ar/diario/ elpais/1-96258-2007-12-16.html>. 20 dic. 2008.

Meyer, Adriana. "La historia sin fin de la ESMA". Página/12. 2 sept. 2008. < http:// www.pagina12.com.ar/diario/elpais/1-110803-2008-09-02.html>. 16 dic. 2008.

Museo de la memoria. "Lugares de Memoria". Rosario, sin fecha. <http:// museodelamemoria.gob.ar/lugares-de-memoria.pdf $>.18$ enero 2009.

Partnoy, Alicia. "Cuando Vienen Matando: On Prepositional Shifts and the Struggle of Testimonial Subjects for Agency". PMLA 121/5 (2006): 1665-69.

The Little School. Tales of Disappearance and Survival. San Francisco: Cleis, 1998.

"On Being Shorter: How Our Testimonial Texts Defy the Academy". Women Writing Resistance. Essays on Latin America and the Caribbean. Jennifer Browdy de Hernandez, ed. Cambridge, MA: South End, 2003. 173-92.

Pastoriza, Lila. "La memoria como política pública"Londres 38. <http://www.londres38. cl/1937/article-85780.html>. 20 julio 2009.

Ricoeur, Paul. Memory, History, Forgetting. Kathleen Blamey y David Pellauer. trads. Chicago: The U of Chicago P, 2004.

Revista Iberoamericana, Vol. LXXVII, Núms. 236-237, Julio-Diciembre 2011, 885-917 
Sarlo, Beatriz. Escenas de la vida posmoderna. Intelectuales, arte y videocultura en la Argentina. Buenos Aires: Ariel, 1994.

"Sobre El antiguo alimento de los héroes". El antiguo alimento de los héroes. Antonio Marimón. Buenos Aires: Puntosur, 1988. 223-230.

Tiempo pasado. Cultura de la memoria y giro subjetivo. Una discusión. Buenos Aires: Siglo XXI, 2005.

"Tiempo pasado. cultura de la memoria y giro subjetivo. Una discusión". Entrevista por Andrea Schulte-Brockohoffe. 10 marzo 2006. <http://edant.clarin. com/suplementos/libros/2006/3/10/1-1048430.htm>. 13 marzo 2011.

Tiempo presente: Notas sobre el cambio de una cultura. Buenos Aires: Siglo XXI, 2001.

Sommer, Doris, ed. e intro. Cultural Agency in the Americas. Durham: Duke UP, 2006.

Taylor, Diana. The Archive and the Repertoire: Performing Cultural Memory in the Americas. Durham: Duke UP, 2003.

"DNA of Performance: Political Hauntology". Cultural Agency in the Americas. Doris Sommer, ed. Durham: Duke UP, 2006. 52-81.

"Trauma and Performance: Lessons from Latin America" PMLA 121/5 (2006): 1674-77.

Vezzetti, Hugo. "Iniciativas políticas de la memoria: el museo en la ESMA". 1 junio 2005. <http://www.elortiba.org/vezzetti.html>. 13 feb. 2009.

Pasado y presente. Buenos Aires: Siglo XXI, 2002.

Viñas, David. Literatura argentina y política II. De Lugones a Walsh. Buenos Aires: Sudamericana, 1996.

Walas, Guillermina. "Autobiografía-etnografía: dos formas de leer un testimonio". Actas del VI Congreso de Literatura Latinoamericana "Homenaje a José Carlos Mariátegui”. Revista CeLeHis 5/3 (1996): 657-63.

"Testimonio de un instrumento ambiguo: la "lengua" en Me llamo Rigoberta Menchú". Revista Documentos Lingüísticos y Literarios UACH. 2007. <http:// www.humanidades.uach.cl/documentos_linguisticos/document.php?id=1339>. 13 feb. 2009.

White, Hayden. The Content of the Form: Narrative Discourse and Historical Representation. Baltimore: Johns Hopkins UP, 1987.

Young, Gerardo “El museo de la ESMArecién estaráterminado para 2010”. Diario Clarín. 23 marzo 2003. <http://www.clarin.com/suplementos/zona/2008/03/23/z-03115. $\mathrm{htm}>.1$ dic. 2008. 
Sitios relevantes al tema:

http://www.museodelamemoria.gov.ar/lugares-de-memoria.pdf

http://www.museodelamemoria.gov.ar/

http://www.memoriaabierta.org.ar

http://portal.educ.ar

http://www.ensenada.gov.ar/relacionescomunitarias/derechoshumanos/2008/0604_

espaciomemoria.php

http://www.nuestroshijos.org.ar/

http://siguiendoeljuicio.blogspot.com/

http://www.institutomemoria.org.ar

$\mathrm{http} / / / \mathrm{www}$.parquedelamemoria.org.ar/home/index.htm

http://www.redh.org/

http://www.historiadelpais.com.ar/conadep.htm

http://www.comisionporlamemoria.org/

http://quememoria.blogspot.com/

http://comunicacion-alterna.blogspot.com/

http://www.elortiba.org/

http://www.culturalaplata.com.ar/

http://www.gacemail.com.ar/Detalle.asp?NotaID=8968

http://www.desaparecidos.org/arg/

http://www.derechos.org/nizkor/arg/informes.html

http://www.abuelas.org.ar

http://www.madresfundadoras.org.ar

http://www.hijos-capital.org.ar

http://www.apdh-argentina.org.ar

http://www.liga.org.ar

http://www.lafogata.org/

http://www.medh.org.ar

http://serpaj-ar.com.ar/spip

http://www.literatura.org/

Diarios:

Página/12

Clarín

Perfil.com

Derf-Agencia Federal de Noticias

Crónica de Argentina

Diario de la Marcha

$\begin{array}{lllll}\text { ISSN 2154-4794 (Electrónico) } & \text { Revista Iberoamericana, Vol. LXXVII, Núms. 236-237, Julio-Diciembre 2011, 885-917 }\end{array}$ 
